\title{
A Framework and Baseline for the Integration of a Sustainable Circular Economy in Offshore Wind
}

\author{
Anne P. M. Velenturf (D) \\ School of Civil Engineering, University of Leeds, Leeds LS2 9JT, UK; A.Velenturf@leeds.ac.uk
}

check for updates

Citation: Velenturf, A.P.M. A Framework and Baseline for the Integration of a Sustainable Circular Economy in Offshore Wind. Energies 2021, 14, 5540. https://doi.org/ $10.3390 /$ en14175540

Academic Editors: Eva Ma Buitrago Esquinas and Rocío Yñiguez Ovando

Received: 15 August 2021

Accepted: 30 August 2021

Published: 5 September 2021

Publisher's Note: MDPI stays neutral with regard to jurisdictional claims in published maps and institutional affiliations.

Copyright: (C) 2021 by the author. Licensee MDPI, Basel, Switzerland. This article is an open access article distributed under the terms and conditions of the Creative Commons Attribution (CC BY) license (https:// creativecommons.org/licenses/by/ $4.0 /)$.

\begin{abstract}
Circular economy and renewable energy infrastructure such as offshore wind farms are often assumed to be developed in synergy as part of sustainable transitions. Offshore wind is among the preferred technologies for low-carbon energy. Deployment is forecast to accelerate over ten times faster than onshore wind between 2021 and 2025, while the first generation of offshore wind turbines is about to be decommissioned. However, the growing scale of offshore wind brings new sustainability challenges. Many of the challenges are circular economy-related, such as increasing resource exploitation and competition and underdeveloped end-of-use solutions for decommissioned components and materials. However, circular economy is not yet commonly and systematically applied to offshore wind. Circular economy is a whole system approach aiming to make better use of products, components and materials throughout their consecutive lifecycles. The purpose of this study is to enable the integration of a sustainable circular economy into the design, development, operation and end-of-use management of offshore wind infrastructure. This will require a holistic overview of potential circular economy strategies that apply to offshore wind, because focus on no, or a subset of, circular solutions would open the sector to the risk of unintended consequences, such as replacing carbon impacts with water pollution, and short-term private cost savings with long-term bills for taxpayers. This study starts with a systematic review of circular economy and wind literature as a basis for the coproduction of a framework to embed a sustainable circular economy throughout the lifecycle of offshore wind energy infrastructure, resulting in eighteen strategies: design for circular economy, data and information, recertification, dematerialisation, waste prevention, modularisation, maintenance and repair, reuse and repurpose, refurbish and remanufacturing, lifetime extension, repowering, decommissioning, site recovery, disassembly, recycling, energy recovery, landfill and re-mining. An initial baseline review for each strategy is included. The application and transferability of the framework to other energy sectors, such as oil and gas and onshore wind, are discussed. This article concludes with an agenda for research and innovation and actions to take by industry and government.
\end{abstract}

Keywords: circular economy; resource and waste management; resource efficiency; wind energy; sustainable development; low-carbon infrastructure; renewable energy; energy transition

\section{Introduction}

Low-carbon infrastructure and technologies such as wind, solar and electric vehicles are important in the mitigation of climate change and to keep global temperature rises below two degrees Celsius [1]. This article focuses on offshore wind because of its fast growth, while the first generation of turbines is about to be decommissioned. Offshore wind has rapidly developed into a preferred technology due to the large potential capacity, reducing costs and high social acceptance. While offshore wind is still dwarfed by onshore wind in terms of installed capacity- $4.8 \%$ of the global wind capacity was offshore by 2020 - it is forecast to accelerate more than ten times faster in terms of growth rates in the period 2021-2025 [2]. The levelised cost of energy for offshore wind are expected to fall at more than twice the speed (55\%) than onshore wind (25\%) between 2018 and 2030 [3]. 
The growing scale, however, also brings new sustainability challenges. Building offshore wind infrastructure will require vast amounts of additional foundation materials, such as steel, copper, concrete and glass fibre, as well as critical materials, such as neodymium and dysprosium [4]. Bigger offshore wind turbines may use more materials per unit of power generated than their smaller predecessors [5]. The freshwater and terrestrial ecotoxicity and human toxicity potentials are the largest adverse impacts from offshore wind, caused by material extraction and component manufacturing [6]. The recycling of offshore wind turbine materials is often depicted as the main strategy to limit future impacts, but research suggests that there is a far greater potential to reduce environmental impacts through improved component durability [7]. It is a challenging balance to strike, though, to design an infrastructure that is durable yet that can be disassembled to enable reuse and recycling [8]. Moreover, the sustainable decommissioning solutions that are required to enable component reuse and high-quality recycling are underdeveloped [9]. These sustainability challenges are related to circular economy and, as this article will substantiate with a review in Section 2, they are not effectively addressed, because circular economy strategies are not commonly and systematically applied to offshore wind.

Circular economy can be understood as the better alternative to the current linear takemake-use-dispose economy. Circular economy contributes to sustainability by minimising natural resource extraction and waste while optimising environmental, social, technical and economic values throughout the lifecycles of materials, components and products [10]. Circular economy brings together an eclectic mix of ideas, such as cleaner production [11-13], industrial ecology [14-18], resource efficiency [19-21], cradle-to-cradle [22,23], regenerative design [24], products-as-service [25-28], natural capital [29-32], zero waste [33-36] and more (further insights in, e.g., [37-39]). Generally speaking, circular economy strategies encompass (1) a narrowing of resource flows in the economy, e.g., by optimising designs using less materials; (2) a slowing of resource flows, e.g., by repairing and reusing products to keep them in use for longer; (3) a closing of resource flows by recycling materials; and (4) integrating resource flows back into natural biogeochemical cycles at the end of their consecutive uses [40,41]. Circular economy is committed to renewable resources, including energy supplies through renewable energy solutions (see, e.g., [42-44]).

The purpose of this article is to enable the integration of a sustainable circular economy into the design, development, operation and end-of-use management of offshore wind infrastructure. Systematically integrating circular economy will require a holistic overview of the potential strategies that apply to offshore wind. Focus on no, or a subset of, circular economy strategies would open the sector to the risk of unintended consequences-for example, growing offshore wind without circular economy considerations could reduce carbon impacts but would likely cause trade-offs with clean water and nature conservation, a focus on recycling could lead to more pollution and costs in comparison to durable designs [45] and the race to reduce costs for the private sector to grow offshore wind in the near-term can lead to higher decommissioning costs that may, moreover, have to be paid by the public later on $[8,46]$. Only four publications include initial circular economy frameworks for wind energy [8,47-49]. This article will evidence that none of these articles meet the full breadth of strategies demanded in offshore wind. Moreover, none fully explain what the circular economy strategies mean for offshore wind, leading to confusion and suboptimal solutions developed in the sector, such as a widespread misconception that circular economy is an end-of-pipe strategy to increase recycling.

The objective of the presented research is to develop a novel framework for a sustainable circular economy in offshore wind through a combination of literature reviews and stakeholder coproduction. Section 2 will systematically review circular economy and wind literature, evidencing that circular economy is not structurally applied to offshore wind and that a holistic framework is lacking, and will explain why such a framework is necessary to effectively address circular economy-related sustainability challenges and opportunities in the offshore wind sector. Section 3 will detail the literature review and stakeholder coproduction process through which the framework was developed. Section 4 will present 
the framework of circular strategies covering the materials, components and infrastructure for offshore wind at all lifecycle stages, briefly comprising: design for circular economy, data and information, recertification, dematerialisation, waste prevention, modularisation, maintenance and repair, reuse and repurpose, refurbish and remanufacturing, lifetime extension, repowering, decommissioning, site recovery, disassembly, recycling, energy recovery, landfill and re-mining. This study thereby also makes an original contribution to the circular economy literature, which is generally product-centric and not focused on a whole infrastructure. Section 4 will also include a baseline review to gauge where major research efforts are required. Section 5 will discuss the application of the framework and the transferability to other energy sectors, and will conclude the article with an agenda for research and innovation and actions for industry and government, including the need for cross-sectoral learning with onshore wind in particular; the development of data systems for the economic, technical, social and environmental values of material, products and component flows into, through and out of offshore wind; better tools for holistic sustainability assessments; insights into the capabilities of related sectors that are essential in supporting circular economy in offshore wind; and context-sensitive decision support tools to optimise whole lifecycle scenarios for offshore wind.

\section{Background: Circular Economy and Offshore Wind}

Circular economy has been defined in hundreds of different ways [50], the only common denominator being the aspiration to make better use of materials, components and products when compared to a linear economy. It has been argued that the purpose of a circular economy is to organise resources to maintain or enhance social well-being and environmental quality for current and future generations, recognising economic prosperity as a boundary condition for sustainable development [10].

Circular economy has gained momentum in industry, government and academia because of its ability to reduce environmental impacts while opening new business opportunities, which can create jobs and other social benefits. Evidence suggests that it is impossible to reach climate targets without realising a sustainable circular economy [51,52]. Environmental benefits stretch further than carbon emission reductions alone, given that a broad spectrum of absolute environmental improvements are increasingly targeted (e.g., [45,53]). However, arguably, it has been the envisaged economic benefits that have made circular economy attractive for governments and businesses [54], with forecasts of $\$ 25$ trillion in new business opportunities globally by 2050 [55] and a potential eight million jobs created in the EU by 2030 (calculated based on [56]).

\subsection{Current Circular Economy Literature on Wind Energy}

This section will show that circular economy strategies are not commonly and explicitly applied to offshore wind, with a systematic review of the scientific literature on circular economy and (offshore) wind that demonstrates the novelty and demand for a circular economy framework for offshore wind. While Liu et al. [57] optimistically stated that "wind power is following the path of sustainable development and circular economy" in 2010, a Scopus search on "circular economy" and "offshore wind" more than ten years later (2 June 2021) returned only six publications-all from the last three years [8,48,58-61]. Pego [58] discusses that renewable energy is a key part of a circular economy, noting that-according to experts on energy and marine spatial planning at the European Commission - the end-of-use management of wind infrastructure is a "fragile point" in the environmental performance.

Jensen [48] argues that 70-80\% of the environmental impact of turbine manufacturing originates from material extraction and processing. Stamford and Azapagic [6] concur, highlighting the importance to maximise resource productivity with measures throughout the lifecycle of a wind farm [8]. While there is a consensus that $80-90 \%$ of materials (by weight) in a turbine could theoretically be recycled, empirical evidence that this is indeed happening is thin [48]. Moreover, recycling ranks relatively low in the hierarchy of circular 
economy strategies, because (a) other strategies such as repair, reuse and remanufacturing generally have a better sustainability potential, and (b) recycling can be energy- and waterintensive while being associated with losses in the material quality and volumes that then have to be substituted in subsequent production cycles [41,62,63]. The largest concerns exist around the recycling of blades due to a lack of commercially available sustainable solutions to recover the composites of which blades are made $[59,64]$.

Overall, the analysis by Jensen et al. [8] shows that offshore wind farms are not generally developed with a circular economy in mind and fail to take a long-term and joined-up perspective regarding resource extraction, use and end-of-use management. Moreover, decommissioning plans are found to be vague with regard to resource management methods and do not provide evidence that materials can and will be sustainably recovered [8], converse to the consensus articulated by Jensen [48] and industry reports (e.g., [65]). Developing and commercialising solutions for end-of-use can be challenging due to limited insights into the resource stocks and flows in offshore wind [66]. The approach of Chen et al. [60] can more accurately estimate the volumes of materials used for foundations in varying water depths. More of such solutions are in demand to better gauge the challenges ahead in terms of the quantities, qualities and timings of resource and waste flows. Here, digital technologies play a crucial role [61].

A broader Scopus search for literature on the interface of the subjects of "circular economy" and "wind" (3 June 2021) returned 91 publications, of which 39 hold direct importance and 27 are peripherally relevant-66 in total (Figure 1). About a third of the 66 titles broadly discuss: the role of wind and other renewable energy technologies to power a sustainable and circular economy [57,58,67-77], or battery storage (e.g., [72,78]) and the potential for integration with a hydrogen economy to avoid a loss of generated wind power (e.g., [79]), using hydrogen subsequently in methanol production [80-82]. Schoden et al. [83] present a project to raise public awareness about the need for a circular economy for wind turbines.

The majority of publications are focused on material recycling and recovery: (a) in general [7,48,84], (b) of blade materials [47,85-96] or (c) of critical raw materials [97-105]. Joining up the start and the end of low-carbon infrastructure supply chains, resource security concerns [102,106,107], design for recycling [108,109] and supply chain security and development $[95,103]$ are covered. Solutions that go beyond material recovery are emerging with publications on lifetime extension [110,111], eco-design [7], reuse and repurposing [83,93,112,113] and remanufacturing [114] - terminology explained in Section 4.

Data systems that offer insight into the quantities and qualities of resource stocks and flows are essential to enable decision-making for the uptake of more circular economy practices [66] and policies and regulations [115]. Initial signs of the development of such systems can be derived from articles on the Internet of Things [61,116], indicators [117] and material stocks and waste flows $[8,49,59,60,89,94]$. Mathews and Huang [118] compare the uptake of renewable energy in China within a global context. Lesniewska [119] discusses EU policy and regulation for a circular economy in solar and wind sectors, and Kopnina [120] talks about renewable energy policy options, comparing reformative energy efficiency measures with more transformative circular economy and cradle-to-cradle approaches. 


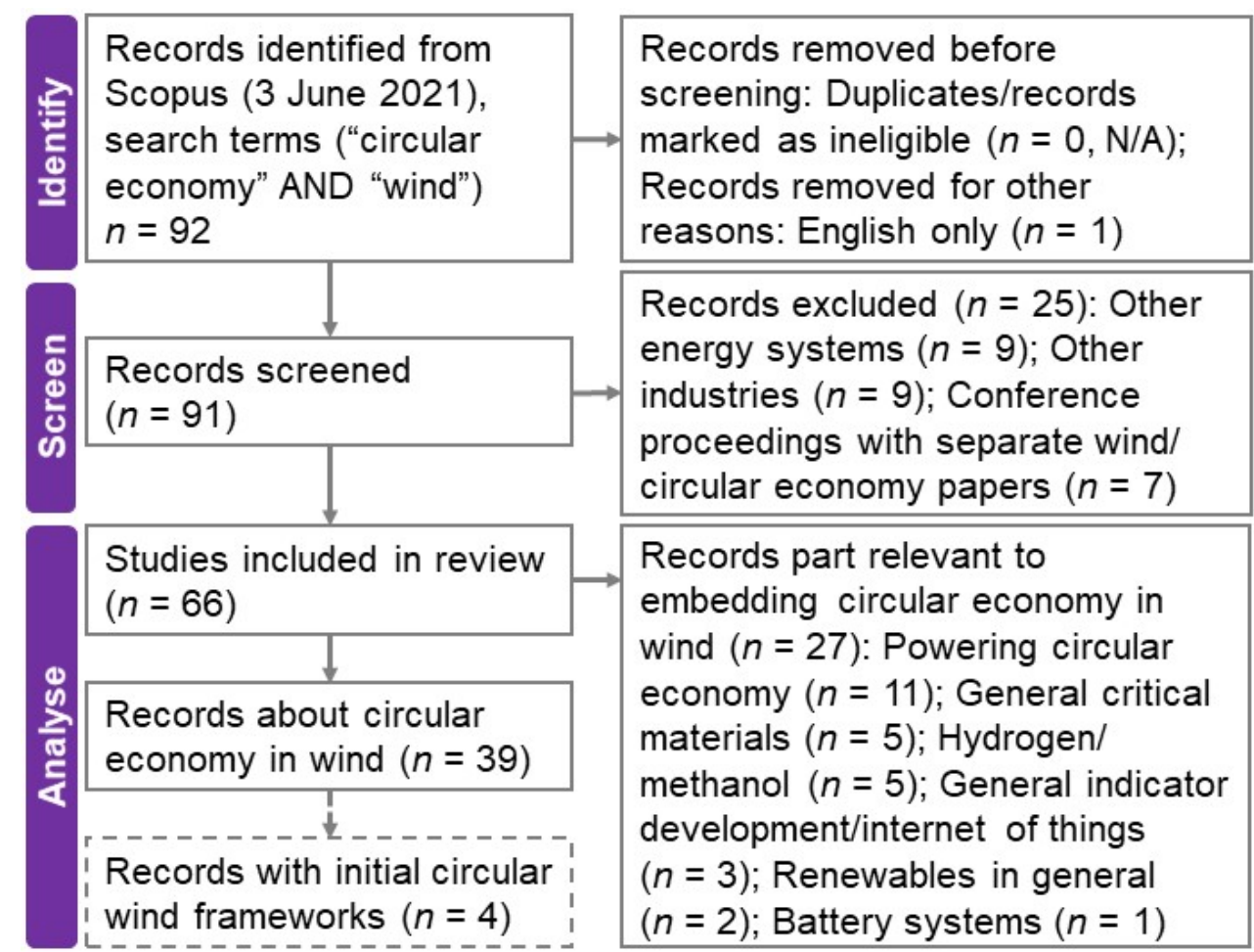

Figure 1. Systematic review of scientific publications on circular economy and wind energy based on the PRISMA guidelines [121].

Four publications include initial circular economy frameworks for the wind sector [8,47-49]. Jensen and Skelton [47] position the current end-of-use solutions for turbine blades within the context of a circular economy diagram, visually similar to the Ellen MacArthur's "butterfly diagram" (an overview and critical review in [41]). The applicability of the framework to other wind turbine components and the whole infrastructure are not part of the study. Conversely, Jensen [48] does discuss recycling solutions for most components. While recycling is placed within the broader context of circular economy-covering longer usage enabled by service and maintenance, reusing products and components and refurbishing/remanufacturing - the estimated relative environmental performance of recycling compared to these circular economy strategies is not discussed. Moreover, this is a single-criterion assessment using energy expenditure as a proxy for environmental performance, missing out on broader environmental factors (e.g., eco/human toxicity) and excluding social and economic factors. In other words, this study does not take a whole system perspective, as would be expected within circular economy. Jensen et al. [8] argue that such limited whole lifecycle and whole system perspectives with regard to resources is pervasive across low-carbon infrastructure sectors. In response, they propose a rudimentary framework for a sustainable circular economy in offshore wind. Similarly, Delaney et al. [49] take the waste hierarchy as a starting point and connect other circular economy practices to it, such as lifetime extension and repair. The frameworks do not explain in detail what each circular economy strategy includes. The latter frameworks indicate that, in offshore wind, there is demand for circular economy strategies that operate at the level of whole infrastructure (e.g., whole turbines and wind farms), while existing circular economy frameworks are generally focused on the product level (also see, e.g., $[122,123])$. These frameworks will be summarised in Section 3 to start developing a circular economy framework that meets the full breadth of demands in offshore wind with greater clarity. 


\subsection{Circular Economy-Related Challenges and Opportunities in Offshore Wind}

Circular economy involves wide-ranging system changes, but at its basis it is about resource and waste management. A literature review and expert survey in 2020 on sustainable development challenges and opportunities for offshore wind revealed a number that are circular economy-related [124]:

Fossil fuels: Moving away from using non-renewable resources such as fossil fuels that contribute to global warming is an opportunity $[6,125,126]$. Nevertheless, reliance on fossil-based materials (e.g., resins) and processes (requiring high temperatures) and the importance of reducing whole lifecycle greenhouse gas emissions remain challenges [124,127-129].

Energy use: While offshore wind power generation can be sustainable, its usage is not necessarily so, and in many countries the per capita energy use has to decrease following the energy hierarchy, a trend already underway with the global energy demand declining $5 \%$ in 2020 [130].

Resource exploitation: The demand for resources for renewable infrastructure is rising steeply [8], raising challenges for environmental sustainability-e.g., due to potential high impacts of resource extraction and processing [6,131]—and social sustainability-e.g., due to slave and child labour and the displacement of indigenous people $[124,132]$. Conversely, opportunities include developing more equitable ownership and business models.

Resource competition for materials is increasing across renewables sectors, especially materials for grid development and for batteries for electric vehicles and large-scale energy storage $[8,133,134]$. Geopolitical dynamics for resource access have been visible for decades, for example, in export restrictions and/or tariffs applied by China on rare earth materials required by industries in Japan, the EU and the US (e.g., [135]) and limiting the manufacturing capacity in India by subjecting raw materials to higher import duties than components. This constrains the capability of countries to break into new global markets for offshore wind, take advantage of opportunities for local industrial development and job creation, and create a ripple effect in which the growing local manufacturing capacity drives further offshore wind deployment [127].

Material innovation solving resource security and sustainability challenges [134,136], including: (a) lifetime extension and component durability, e.g., better blade coatings and materials (e.g., [137]) and lighter materials reducing structural loads [138]; (b) more resilient materials for the marine environment with less pollution potential through harmful leakage into the sea; (c) alternatives to fossil-based materials, e.g., replacing resins in blades and SF6 in switchgear; (d) components and materials to disassemble and recycle easily [8]; (e) alternatives for critical raw materials. However, early warning signs were raised that ongoing cost reductions start to limit funds for industry innovation.

Durability and lifetime extension are crucial for increasing the resource productivity of materials, e.g., extending the component lifetime from 20 to 30 years can increase the resource productivity by $50 \%$ and significantly reduce the relative environmental impacts of resource extraction and processing. This requires understanding the state of individual components and whole offshore wind structures throughout their lifecycle, and operations and maintenance (O\&M) with the help of robotics and remote monitoring can improve insights, especially when combined with better data systems to capture, share and use data across the supply chain, which may be constrained by proprietary systems $[66,134,136]$. Better insights into material stocks and flows are also important for decision-making for business models, policies and investments into circular economy solutions [66], with data on the volumes, material properties and associated environmental, social and economic values of products, components and materials [139]. Supply chains are considered complex, because stakeholders can play multiple roles across projects (e.g., OEMs-Original Equipment Manufacturers - can also own wind farms or function as operations and maintenance providers) [140], and because market conditions and contractual terms can strongly vary, especially at end-of-use [141]. 
End-of-use management: Growing concerns around resource access and the social and environmental impacts require sustainable solutions for end-of-use management. The impact of material usage in offshore wind is relatively high compared to other power technologies in terms of potential water, human and ecotoxicity and tend to be justified by the assumption that materials can be recycled [6,127,141]. However, the issues around endof-use management and recycling are prevalent $[8,66]$, particularly regarding blade waste from replacements and decommissioning operations due to the lack of sustainable and commercially viable recycling solutions [8,59]. This is exacerbated by long-running circular economy challenges with regards to finding end users for recycled materials, relatively low costs of virgin materials and low costs of less-sustainable solutions [59]. Supply chains for offshore wind decommissioning, associated infrastructure and end-of-use management are still to be developed $[9,66]$.

Sustainable decommissioning: Offshore wind end-of-use management and decommissioning experiences are limited [141]. While decommissioning is often only considered as an afterthought [141], it could be eased proactively with "design for decommissioning", for example, designing sites upfront to enable a retrofit with bigger turbines at the endof-use. Working in marine conditions poses challenges due to the logistics and diverse weather conditions [141,142]. Future (de)commissioning could be eased by floating wind farms where some operations can occur closer to shore. The lack of specific and suitable regulations for offshore wind increases the uncertainty in decommissioning processes and allows for inadequate plans to be articulated, with offshore wind infrastructure being constructed without plans for the recovery of materials and/or obligations to develop such solutions when they are absent at the point of construction [8,141]. The lack of proactive planning can affect the decommissioning costs, with offshore wind decommissioning costs four-to-ten times higher than expected, while financial securities are not keeping up sufficiently $[8,46,141,143]$. These issues were previously experienced by other sectors, e.g., North Sea oil and gas, with a high potential for cross-sectoral learning regarding cost management, decommissioning technologies and reusing infrastructure from other sectors.

\section{Methods}

\subsection{Developing the Framework}

In August 2020 a draft framework of circular economy strategies for offshore wind was developed through a systematic review of the scientific literature on wind energy that included overviews of circular economy strategies (Section 2.1). The three articles that included initial frameworks and were available at the time $[8,47,48]$ were used as a starting point (Table 1). The identified strategies contained duplications around processes describing the recovery of materials. These were recycling, recovery and conversion, which describe processes that, under the legal terms of the waste hierarchy, would all be considered recycling and, therefore, were consolidated into one strategy. Resize/reshape describes a process that, in circular economy, is commonly called "repurpose" and was reworded as such.

The circular economy strategies from Table 1 were discussed in a workshop with the Offshore Renewable Energy Catapult in August 2020 (a UK government-funded leading technology innovation and research centre for offshore renewable energy) to brainstorm about how circular economy terminology intersects with language in offshore wind (overview of the results in Table 2). In parallel, an initial exploration of the scientific literature on the individual circular economy strategies and offshore wind was carried out. This led to adaptations of the terminology used in the framework. Dematerialisation and waste prevention came up in the review and were discussed in the workshop, and are clearly reflected as important in circular economy literature and the waste hierarchy. These strategies were, hence, added to the framework. The groupings of the strategies reuse, refurbish, upgrade and remanufacture were altered, respectively, based on the processes described. The difference between reuse and repurpose became fuzzy in discussions and, with the difference appearing minimal, were merged into reuse. Re-mining was added to express the 
potential to recover resources from landfilled wastes for use in low-carbon infrastructure. Replanting was dropped, because the term is not commonly used. Disassembly was added due to the importance for enabling component reuse, recycling, etc. The discussion with the Offshore Renewable Energy Catapult offered a vital source of alternative keywords that were used as search terms for further exploration of the literature. The interactions also underlined the diverse interpretations of circular economy terminology and the value of offering a framework with clear descriptions to enable the effective integration of circular economy within the offshore wind industry.

The draft framework was communicated with the waste, resources and offshore wind sectors in the period September-December 2020 via blogposts [144,145], presentations, podcasts and interviews at industry events inviting expert feedback [146-150]. Feedback included clarification questions and suggestions regarding individual strategies, suggestions for additional strategies (modularisation and recertification, and making the difference between reuse and repurpose explicit) and to complement and ease the legibility of the accompanying diagram, and questions about how to use the framework (subsequently covered in the discussion of this article).

The framework went through a third and final step of stakeholder input at a business workshop in January 2021 [151]. The workshop was attended by 112 participants from industry $(49 \%)$, government $(10 \%)$, research, development and innovation organisations $(36 \%)$, and other organisations (5\%) in various offshore wind and related sectors in the supply chain, including, for example, the wind, removal services, and resources and waste sectors. The participants were missing a number of strategies from the presentation of the framework, including: Coprocessing (covered under recycling/energy recovery); Lifetime extension through derating (specification under lifetime extension); Degrowth (economic model rather than a circular economy strategy); and Information strategies (added to the strategies as a key enabler).

Table 1. Initial circular economy framework for offshore wind based on the scientific literature $[8,47,48]$. Grey cells indicate the initial frameworks that named the circular economy strategies. "N/A" indicates that descriptions of named strategies were missing in the publication(s).

\begin{tabular}{|c|c|c|c|c|}
\hline Circular Economy Strategy & Strategy Description & $\begin{array}{l}\text { Jensen and Skelton } \\
2018\end{array}$ & $\begin{array}{l}\text { Jensen } \\
2019\end{array}$ & $\begin{array}{l}\text { Jensen et al. } \\
2020\end{array}$ \\
\hline Design for circularity & $\begin{array}{l}\text { Balancing durability, reparability, disassembly } \\
\text { and recyclability at design stage }\end{array}$ & & & \\
\hline Service, maintenance & $\mathrm{N} / \mathrm{A}$ & & & \\
\hline Repair & $\mathrm{N} / \mathrm{A}$ & & & \\
\hline Reuse, redistribution & $\begin{array}{l}\text { Reuse of the whole blade in its current } \\
\text { structure; of products and components }\end{array}$ & & & \\
\hline Repurpose; Resize/reshape & $\begin{array}{l}\text { Standardized and custom-made parts } \\
\text { made from the blade and used for } \\
\text { secondary applications }\end{array}$ & & & \\
\hline Remanufacture/refurbish & $\mathrm{N} / \mathrm{A}$ & & & \\
\hline $\begin{array}{l}\text { Recycling; Recovery; } \\
\text { Conversion }\end{array}$ & $\begin{array}{l}\text { Recycled material used in secondary } \\
\text { applications as aggregates. Waste management } \\
\text { processes to extract fibres and resin to retain } \\
\text { best possible quality. Converting the composite } \\
\text { material into new materials for other purposes }\end{array}$ & & & \\
\hline Energy recovery & $\mathrm{N} / \mathrm{A}$ & & & \\
\hline Landfill/controlled storage & $\mathrm{N} / \mathrm{A}$ & & & \\
\hline Lifetime extension & $\begin{array}{l}\text { Extending the life of a whole } \\
\text { wind farm }\end{array}$ & & & \\
\hline Site replanting & Replanting sites with similar turbines & & & \\
\hline Site repowering & Replacing turbines with larger models & & & \\
\hline $\begin{array}{l}\text { Decommissioning/site } \\
\text { restoration }\end{array}$ & $\begin{array}{l}\text { Remove turbines and restore site to conditions } \\
\text { similar to before the development }\end{array}$ & & & \\
\hline
\end{tabular}


Table 2. Results from the workshop with the Offshore Renewable Energy Catapult in August 2020.

\begin{tabular}{|c|c|}
\hline Circular Economy Strategy & Alternative Terminology Raised in Workshop \\
\hline Design for circular economy/circularity & $\begin{array}{l}\text { Ecoselector, Product environmental design } \\
\text { Holistic lifetime design, Integrated design }\end{array}$ \\
\hline Repair, Maintenance & $\begin{array}{c}\text { O\&M (operations and maintenance), Inspection, Service, PPM/planned } \\
\text { preventative maintenance, Condition based maintenance } \\
\text { Scheduled and unscheduled } \\
\text { Troubleshooting (or T/S) } \\
\text { Component replacement/exchange, Retrofit } \\
\text { Jacked-up events, Event of crane demand }\end{array}$ \\
\hline Reuse, Repurpose & $\begin{array}{c}\text { Refurbished } \\
\text { Breaking (e.g., breaking up, breaking for parts), Salvage } \\
\text { Second-hand, Used }\end{array}$ \\
\hline Refurbish, Remanufacturing & $\begin{array}{l}\text { Upgrade, Overhaul } \\
\text { Refurb } \\
\text { Recon/reconditioned } \\
\text { Parts }\end{array}$ \\
\hline Recycling & $\begin{array}{l}\text { Scrap (in relation to metal) } \\
\text { Diversion (from landfill) }\end{array}$ \\
\hline Energy recovery & $\begin{array}{l}\text { Waste to heat, Waste to energy, Energy from waste, Incineration, Burning, } \\
\text { Pyrolysis, gasification, etc. }\end{array}$ \\
\hline Landfill, Controlled storage & $\begin{array}{l}\text { Burial, Burying } \\
\text { Re-mining }\end{array}$ \\
\hline Lifetime extension & $\begin{array}{l}\text { Asset life management, Asset life extension } \\
\text { Fatigue life extension, End of life extension } \\
\text { Remaining life; Residual strength determination; Digital twin } \\
\text { Leading edge protection, Cathodic protection, Corrosion prevention } \\
\text { End of life }\end{array}$ \\
\hline Replanting & Not commonly used. If used, means process similar to repowering. \\
\hline Repowering & $\begin{array}{l}\text { Full/partial repowering } \\
\text { End of life extension }\end{array}$ \\
\hline Decommissioning & $\begin{array}{c}\text { Removal/Asset removal; Extraction } \\
\text { Dismantling } \\
\text { End of life }\end{array}$ \\
\hline Site restoration & $\begin{array}{l}\text { Site recovery, Artificial reefs, Habitat restoration, Aftercare } \\
\text { Foundation cutting, Monopile extraction }\end{array}$ \\
\hline Other terms from open discussion & $\begin{array}{c}\text { Remediation } \\
\text { Waste reduction, Waste prevention } \\
\text { Lifecycle management } \\
\text { Lean manufacturing, Dematerialisation } \\
\text { Overhaul } \\
\text { Rebuild } \\
\text { Reprocess } \\
\text { Re-energise }\end{array}$ \\
\hline
\end{tabular}

\subsection{Reviews to Define and Take a Baseline of the Identified Strategies}

Each of the identified circular economy strategies were defined for the purpose of generating clarity in their application. Interactions with practitioners (see Section 3.1) displayed confusion about the meaning of circular economy strategies. While presenting the broad diversity of perspectives on each strategy could be seen as more objective, it can also feed further-counterproductive-confusion. Hence a strategic choice was made to select circular economy literature to define strategies based on the consensus that they derived from a diversity of perspectives reviewed and/or their apparent thought 
leadership based on novelty (for newer strategies) and the number of citations (for more established strategies).

Subsequently, an initial baseline review was carried out on research on each circular economy strategy within the subject area of offshore wind, consisting of three steps (Table 3): (a) searching for the key term(s) named in circular economy for offshore wind framework, (b) searching for the associated terms as identified in Table 2 and (c) searching for key term(s) in the broader wind energy literature. The first step of the reviews was systematic for nearly all the strategies, except for repair and maintenance, data and information and circular design, because these represented large and fuzzy bodies of the literature with thousands of publications that could not be covered within the time available for this project. Each strategy would deserve a further in-depth review in their own right, but that went beyond the purpose of this baseline review, which was to gauge the current expertise in offshore wind to inform an agenda for research and practice in the-new to offshore wind-subject area of circular economy.

Table 3. Literature searches for keywords in the publication title, abstract or keywords on Scopus (last repeated on 5 and 6 June 2021, unless specified otherwise) for three consecutive searches on (a) circular economy strategies in offshore wind, (b) associated terms in offshore wind based on Table 2 and (c) circular economy strategies in wind energy in general.

\begin{tabular}{|c|c|c|}
\hline Circular Economy Strategy & & Search Terms \\
\hline \multirow{3}{*}{ 1. Dematerialise } & a & (("offshore wind" OR off-shore wind") AND (dematerial* OR de-material*)) \\
\hline & $\mathrm{b}$ & ((“offshore wind" OR off-shore wind") AND (“lean manufacturing")) \\
\hline & c & $\left(\left(\right.\right.$ ("wind") AND (dematerial* OR de-material $\left.\left.^{*}\right)\right)$ \\
\hline \multirow{3}{*}{ 2. Prevent waste } & a & $\begin{array}{l}\text { - (("offshore wind" OR "off-shore wind") AND ("waste prevention" OR "prevent waste")) } \\
\text { - (("offshore wind" OR "off-shore wind") AND ("industrial symbiosis")) }\end{array}$ \\
\hline & $\mathrm{b}$ & ((“offshore wind" OR “off-shore wind”) AND (“waste reduction" OR “reduce waste”)) \\
\hline & c & $\begin{array}{l}\bullet((\text { wind") AND ("waste prevention" OR “prevent waste")) } \\
\bullet((\text { "wind") AND ("industrial symbiosis")) }\end{array}$ \\
\hline \multirow{3}{*}{ 3. Maintain and repair } & a & $\begin{array}{l}\text { - (("offshore wind" OR “off-shore wind") AND repair*) } \\
\text { - (("offshore wind" OR "off-shore wind") AND "maintenance") }\end{array}$ \\
\hline & $\mathrm{b}$ & $\begin{array}{l}\text { - (("offshore wind" OR "off-shore wind") AND (inspection)) } \\
\text { - (("offshore wind" OR "off-shore wind") AND (service)) } \\
\text { - (("offshore wind" OR "off-shore wind") AND (O\&M)) } \\
\text { • (("offshore wind" OR "off-shore wind") AND (retrofit)) } \\
\text { - (("offshore wind" OR "off-shore wind") AND ("trouble shooting")) } \\
\text { - (("offshore wind" OR "off-shore wind") AND ("component replacement" OR } \\
\text { "component exchange")) } \\
\text { - (("offshore wind" OR "off-shore wind") AND ("jacked-up event")) }\end{array}$ \\
\hline & c & $\begin{array}{l}\bullet \text { ("wind" AND repair*) } \\
\text { - ("wind" AND "maintenance") }\end{array}$ \\
\hline \multirow{3}{*}{ 4. Reuse and repurpose } & a & $\begin{array}{l}\text { - (("offshore wind" OR “off-shore wind") AND ("reuse" OR "re-use" OR reus*)) } \\
\text { • (("offshore wind" OR “off-shore wind") AND ("repurpose" OR "re-purpose" } \\
\text { OR repurpos*)) }\end{array}$ \\
\hline & $\mathrm{b}$ & $\begin{array}{l}\text { - (("offshore wind" OR “off-shore wind") AND ("used" AND “parts") } \\
\text { - (("offshore wind" OR "off-shore wind") AND ("breaking" AND "parts") }\end{array}$ \\
\hline & C & $\begin{array}{l}\text { • ((“wind") AND ("reuse" OR “re-use" OR reus*)) } \\
\text { • (("wind") AND ("repurpose" OR "re-purpose" OR repurpos*)) }\end{array}$ \\
\hline
\end{tabular}


Table 3. Cont.

\begin{tabular}{|c|c|c|}
\hline Circular Economy Strategy & & Search Terms \\
\hline \multirow{3}{*}{ 5. Lifetime extension } & a & (("offshore wind" OR “off-shore wind") AND ("lifetime extension")) \\
\hline & $\mathrm{b}$ & $\begin{array}{l}\text { - (("offshore wind" OR "off-shore wind") AND ("asset life")) } \\
\text { - (("offshore wind" OR "off-shore wind") AND ("fatigue life")) } \\
\text { - (("offshore wind" OR "off-shore wind") AND ("end of life extension")) } \\
\text { - (("offshore wind" OR "off-shore wind") AND ("remaining life")) } \\
\text { - (("offshore wind" OR "off-shore wind") AND ("residual strength")) } \\
\text { - (("offshore wind" OR "off-shore wind") AND ("digital twin")) } \\
\text { - (("offshore wind" OR "off-shore wind") AND ("derating")) }\end{array}$ \\
\hline & c & $\begin{array}{l}\text { - (("wind") AND (“lifetime extension")) } \\
\text { - (("wind") AND ("fatigue life")) }\end{array}$ \\
\hline \multirow{3}{*}{ 6. Repower } & a & (("offshore wind" OR “off-shore wind") AND ("re-power*" OR repower*)) \\
\hline & $\mathrm{b}$ & $\begin{array}{l}\text { - (("offshore wind" OR “off-shore wind") AND ("replanting")) } \\
\text { - (("offshore wind" OR “off-shore wind") AND ("end of life extension")) }\end{array}$ \\
\hline & c & ((“wind") AND ("re-power*" OR repower*)) \\
\hline \multirow{3}{*}{$\begin{array}{l}\text { 7. Refurbish and } \\
\text { remanufacture }\end{array}$} & a & $\begin{array}{l}\text { - (("offshore wind" OR "off-shore wind") AND ("refurbish*" OR “re-furbish*")) } \\
\text { • (("offshore wind" OR "off-shore wind") AND ("remanufactur" OR “re-manufactur*")) }\end{array}$ \\
\hline & $\mathrm{b}$ & $\begin{array}{l}\text { - (("offshore wind" OR “off-shore wind") AND ("upgrade")) } \\
\text { • (("offshore wind" OR "off-shore wind") AND ("overhaul")) } \\
\text { • (("offshore wind" OR "off-shore wind") AND ("recondition")) } \\
\text { - (("offshore wind" OR “off-shore wind") AND ("parts")) }\end{array}$ \\
\hline & c & 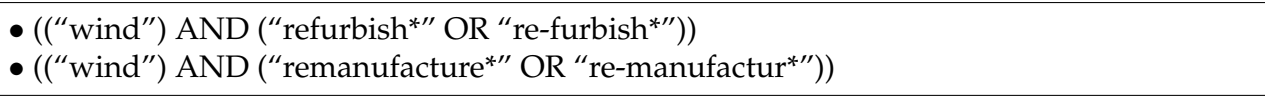 \\
\hline \multirow{3}{*}{ 8. Recertify } & a & $(($ ("offshore wind" OR “off-shore wind") AND ("recertify*” OR “re-certif*)) \\
\hline & $\mathrm{b}$ & (("offshore wind" OR “off-shore wind") AND (certify*)) \\
\hline & c & $\begin{array}{l}\text { - }((\text { ("wind") AND (“recertif*” OR “re-certif*)) } \\
\text { - (("wind") AND (certif*)) }\end{array}$ \\
\hline \multirow{3}{*}{ 9. Disassemble } & a & (("offshore wind" OR “off-shore wind") AND (disassembl*)) \\
\hline & $\mathrm{b}$ & $\mathrm{N} / \mathrm{A}$ \\
\hline & $\mathrm{c}$ & $((“$ wind”) AND (disassembl*)) \\
\hline \multirow{3}{*}{ 10. Modularisation } & a & $\begin{array}{l}\text { - (("offshore wind" OR “off-shore wind") AND (modular*)) } \\
\text { • (("offshore wind" OR "off-shore wind") AND ("modularisation" OR "modular design")) }\end{array}$ \\
\hline & $\mathrm{b}$ & $\mathrm{N} / \mathrm{A}$ \\
\hline & c & $\begin{array}{l}\text { - }((\text { ("wind”) AND (modular*)) } \\
\text { • (("wind") AND ("modularisation" OR “modular design")) }\end{array}$ \\
\hline \multirow{3}{*}{ 11. Decommission } & a & $(($ "offshore wind" OR “off-shore wind") AND (decommission*)) \\
\hline & $\mathrm{b}$ & $\begin{array}{l}\text { - (("offshore wind" OR “off-shore wind") AND ("asset removal”)) } \\
\text { - (("offshore wind" OR “off-shore wind") AND ("removal")) } \\
\text { - (("offshore wind" OR "off-shore wind") AND (dismantl*)) } \\
\text { - (("offshore wind" OR “off-shore wind") AND (extraction)) }\end{array}$ \\
\hline & $\mathrm{c}$ & $(($ ("wind") AND (decommission*)) \\
\hline \multirow{3}{*}{ 12. Restore site } & a & $\begin{array}{l}\text { - (("offshore wind" OR "off-shore wind") AND ("site recovery" OR "recover site")) } \\
\text { • (("offshore wind" OR "off-shore wind") AND ("site restoration" OR "restore site")) }\end{array}$ \\
\hline & $\mathrm{b}$ & $\begin{array}{l}\text { - (("offshore wind" OR "off-shore wind") AND ("artificial reefs")) } \\
\text { - (("offshore wind" OR "off-shore wind") AND ("habitat restoration")) } \\
\text { - (("offshore wind" OR "off-shore wind") AND ("aftercare")) } \\
\text { - (("offshore wind" OR "off-shore wind") AND ("foundation cutting")) } \\
\text { - (("offshore wind" OR "off-shore wind") AND ("monopile extraction")) }\end{array}$ \\
\hline & c & $\begin{array}{l}\text { - (("wind") AND ("site recovery" OR "recover site")) } \\
\text { - }((\text { ("wind") AND ("site restoration" OR "restore site")) }\end{array}$ \\
\hline
\end{tabular}


Table 3. Cont.

\begin{tabular}{|c|c|c|}
\hline Circular Economy Strategy & & Search Terms \\
\hline \multirow{3}{*}{ 13. Recycle } & $\mathrm{a}$ & (("offshore wind" OR “off-shore wind") AND (recycl*)) \\
\hline & $\mathrm{b}$ & $\begin{array}{l}\text { - (("offshore wind" OR “off-shore wind") AND ("scrap")) } \\
\text { - On } 30 \text { December 2020: ((recycle*) AND "steel")) } \\
\text { - On } 30 \text { December 2020: ((recycle*) AND “concrete") } \\
\text { - }((\text { recycle*) AND “glass fibre reinforced composite") } \\
\text { - }\left(\left(\text { recycle }^{*}\right) \text { AND "critical materials") }\right.\end{array}$ \\
\hline & c & $(($ (wind") AND (recycl*)) \\
\hline \multirow{3}{*}{ 14. Recover energy } & a & (("offshore wind" OR "off-shore wind") AND ("energy recovery")) \\
\hline & $\mathrm{b}$ & $\begin{array}{l}\text { - (("offshore wind" OR “off-shore wind") AND ("energy-from-waste")) } \\
\text { - (("offshore wind" OR "off-shore wind") AND ("waste-to-heat")) } \\
\text { - (("offshore wind" OR "off-shore wind") AND ("incineration" OR "burning")) } \\
\text { - (("offshore wind" OR "off-shore wind") AND ("pyrolysis")) } \\
\text { - (("offshore wind" OR "off-shore wind") AND ("gasification")) } \\
\text { - (("offshore wind" OR "off-shore wind") AND ("solvolysis")) } \\
\text { - (("offshore wind" OR “off-shore wind") AND ("thermal treatment")) }\end{array}$ \\
\hline & c & $(($ "wind") AND ("energy recovery")) \\
\hline \multirow{3}{*}{ 15. Landfill } & $\mathrm{a}$ & (("offshore wind" OR “off-shore wind") AND ("landfill*”)) \\
\hline & $\mathrm{b}$ & $\begin{array}{l}\text { - (("offshore wind" OR "off-shore wind") AND ("controlled storage")) } \\
\text { - (("offshore wind" OR "off-shore wind") AND ("burial" OR "burying")) }\end{array}$ \\
\hline & c & ((“wind") AND (“landfill*”)) \\
\hline \multirow{3}{*}{ 16. Re-mine } & $\mathrm{a}$ & (("offshore wind" OR “off-shore wind") AND ("re-mine")) \\
\hline & $\mathrm{b}$ & ((“offshore wind" OR “off-shore wind") AND (“urban mining”)) \\
\hline & c & ((“wind") AND ("re-mine")) \\
\hline \multirow{3}{*}{$\begin{array}{l}\text { 17. Data and } \\
\text { information }\end{array}$} & $\mathrm{a}$ & (("offshore wind" OR “off-shore wind") AND ("data system" AND “information")) \\
\hline & $\mathrm{b}$ & $\begin{array}{l}\text { - (("offshore wind" OR "off-shore wind") AND ("data" AND “lifecycle")) } \\
\text { - (("offshore wind" OR "off-shore wind") AND ("sustainability assessment")) } \\
\text { • (("offshore wind" OR "off-shore wind") AND ("sustainability" AND "indicators")) } \\
\text { - (("offshore wind" OR "off-shore wind") AND ("data standards")) } \\
\text { • (("offshore wind" OR "off-shore wind") AND ("data sharing")) }\end{array}$ \\
\hline & c & ((“wind”) AND (“data system” AND “information")) \\
\hline \multirow{3}{*}{$\begin{array}{l}\text { 18. Design for } \\
\text { circularity }\end{array}$} & a & ((“offshore wind" OR “off-shore wind") AND (“design*”) AND (“circular economy”)) \\
\hline & $\mathrm{b}$ & $\begin{array}{l}\text { - (("offshore wind" OR "off-shore wind") AND ("ecoselector") } \\
\text { - (("offshore wind" OR “off-shore wind") AND ("product environmental design") } \\
\text { - (("offshore wind" OR “off-shore wind") AND ("holistic" AND “design") } \\
\text { - (("offshore wind" OR “off-shore wind") AND ("integrated design") }\end{array}$ \\
\hline & $\mathrm{c}$ & ((“wind") AND (“design*”) AND (“circular economy")) \\
\hline
\end{tabular}

\section{Results: Circular Economy Framework for Offshore Wind}

The finalised framework includes eighteen circular economy strategies (Figure 2) organised by their application to materials, components and whole infrastructure, and by strategy type, i.e., narrowing, slowing, closing and integrating resource flows (as introduced in Section 1) throughout the lifecycle of offshore wind infrastructure from design to end-ofuse and beyond. The definitions of each strategy and the relations between the strategies will be discussed hereafter, followed by baseline reviews to identify major knowledge gaps. The application of the framework within offshore wind and the transferability to other sectors will be covered in Section 5. 


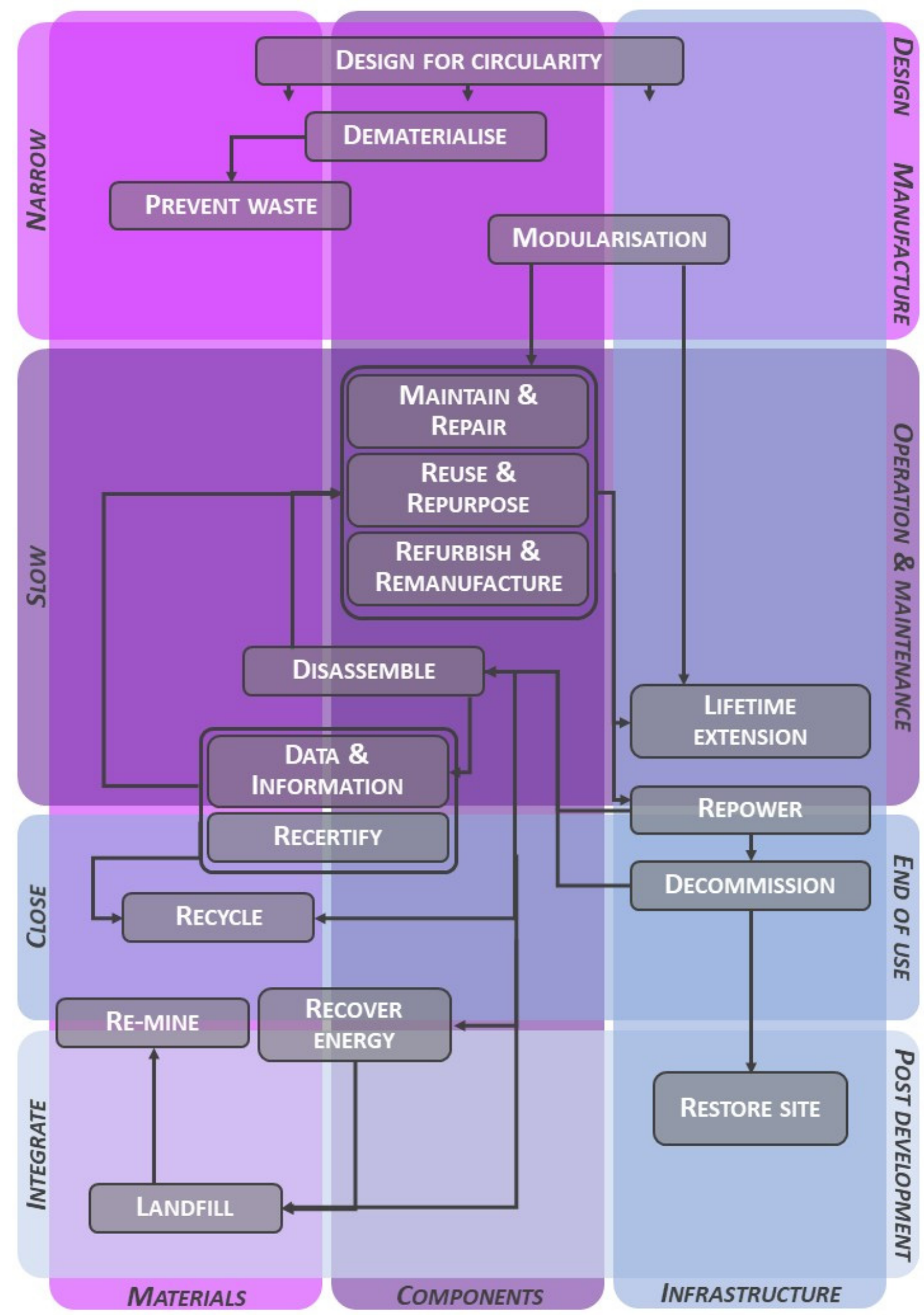

Figure 2. Circular economy strategies for offshore wind organised by their application to materials, components and whole infrastructure (columns), the narrowing, slowing and closing of resource flows and their integration into the environment (rows, left side), throughout the offshore wind infrastructure lifecycle, from design to the end-of-use and beyond (rows, right side). Arrows indicate that one strategy enables another-for example, disassembly enables remanufacturing, and maintenance and repair enable lifetime extension. 


\subsection{Dematerialisation}

Dematerialisation is about reducing resource use. It is one of the most effective approaches to reduce costs and environmental impacts. At a whole system level, dematerialisation is an essential part of achieving a sustainable circular economy. Circulating resources within society, through whichever circular economy strategy, generally costs energy, water and the addition of new materials $[41,62,63]$. Maintaining the current levels of material use is unlikely to become sustainable, and therefore the total volumes of materials within the economies of developed countries must be reduced [152-154].

Dematerialisation for offshore wind includes the exploration of reduced resource use through, for example, shape optimisation and alternative materials. While Bakker et al. [155] implies that designing products with less materials is common practice because it reduces costs, Andrews [156] argues that such a circular economy strategy is not normally part of designers' mindsets. Moreover, there may be a trade-off between dematerialisation and designing for reliability [40] due to high safety margins in high-risk sectors. Additionally, reduced resource use could affect component durability, thereby introducing a potential trade-off with, for example, component reuse (Section 4.4) and lifetime extension (Section 4.5).

There are currently no scientific articles published on dematerialisation in offshore wind (search in Table 3 and results in Figure 3). A deeper search covering wind energy in general revealed ten publications on dematerialisation, but only one appears relevant to wind power based upon scanning the abstracts [157] while the others cover the dematerialisation of society in more general terms (e.g., [118]). The accompanying term "lean manufacturing" (search in Table 3) also did not recover further publications on offshore wind. Dematerialisation may be more prevalent under the banner of various design terms (Section 4.18).

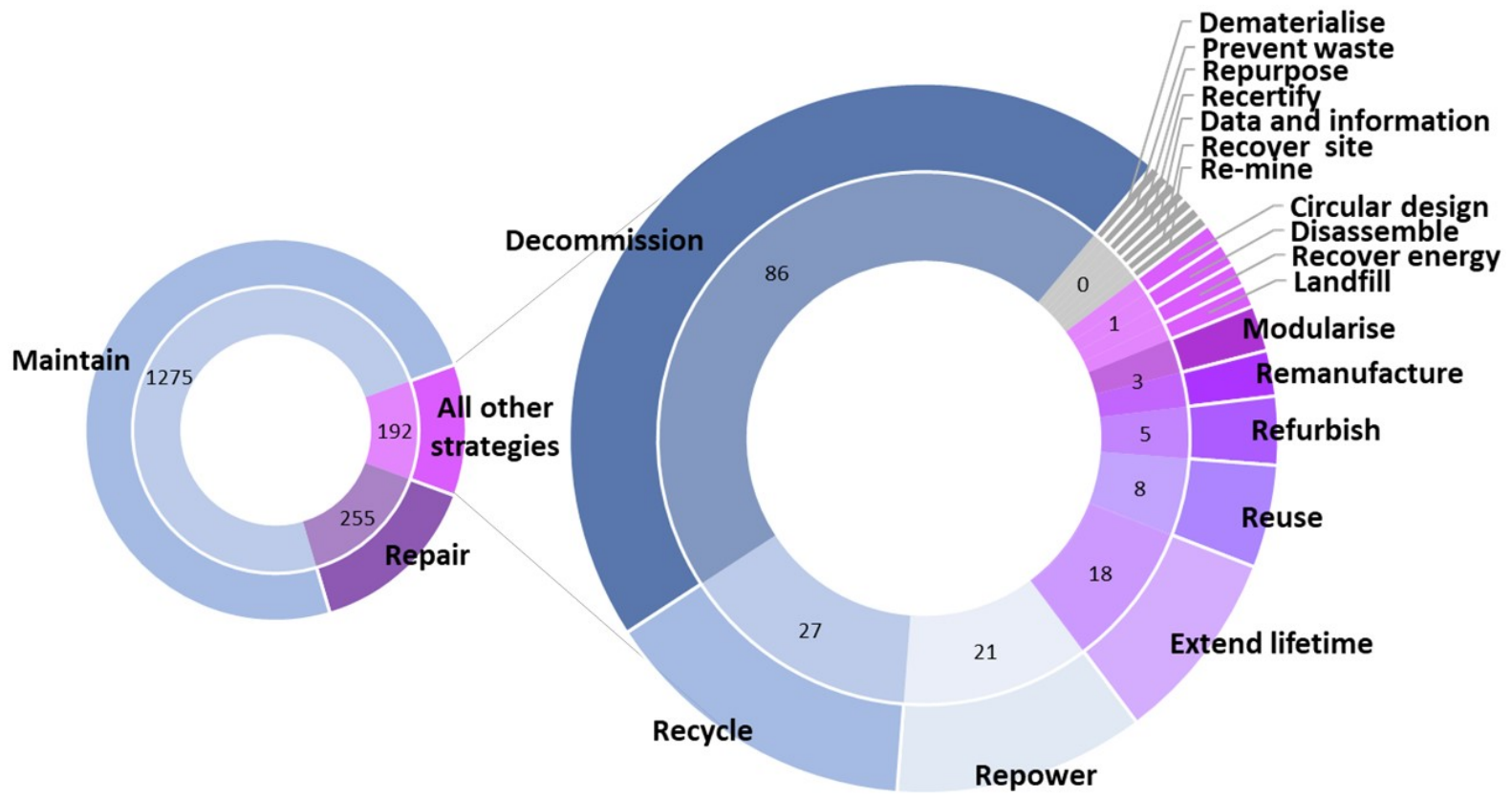

Figure 3. Overview of the number of scientific publications on circular economy strategies in offshore wind (based on Scopus searches on 5 and 6 June 2021).

\subsection{Waste Prevention}

The reduction of resource use is often conflated with a reduction of waste [123], because the latter is expected to logically be prevented by the use of less and less hazardous materials while using materials for longer [158]. Herein, however, waste prevention is included as a separate strategy to enable a more transparent application. Preventing waste 
is about eliminating waste from production rather than having to deal with waste once it has emerged [123,159].

Wastes can be proactively designed out, or they can be put to valuable use through industrial symbiosis (e.g., [160]). Industrial symbiosis can be described as "the establishment of close working agreements between normally unrelated companies that lead to resource efficiency. Working agreements include, among other, the direct reuse of one company's waste stream as another's raw material, the innovative reprocessing of problematic by-products and the sharing of underutilised power, water and/or steam" [161].

Waste prevention, industrial symbiosis and recycling can be confusing to distinguish. Waste prevention and industrial symbiosis are proactive and positioned at the design and manufacturing stages, while recycling is generally positioned at the end-of-use of products and components (Section 4.13). Waste prevention should not be confused with the use of recycled materials. By definition, if a recyclate exists, then it has been a waste, and the waste was not prevented from emerging in the first place, which is the purpose of waste prevention.

No publications on offshore wind and waste prevention or industrial symbiosis were identified (search in Table 3 and results in Figure 3). A broader search on wind and waste prevention reveals five publications, none of which are about waste prevention in the manufacturing of wind infrastructure components. Scopus holds eight publications on wind and industrial symbiosis, one of which is somewhat relevant. Huang et al. [84] present a wind and solar infrastructure design using renewable wood and recycled metals. There may be more relevant publications, because industrial symbiosis is linked to the development of multifunctional systems that avoid underutilisation of the infrastructure, combining, for example, offshore wind with desalination (e.g., [162]) and integrating wind into optimised energy systems (e.g., [163]). Alternative searches on "waste reduction" or "reduce waste" (Table 3) return one article that is not about waste prevention but, rather, about the repurposing of oil and gas infrastructure [164].

\subsection{Repair and Maintenance}

Repair and maintenance are strategies to increase the duration over which a componentand, thereby, a whole infrastructure (Section 4.5) - is in operation. Maintenance and repairs can be preventative, planned or ad hoc in response to faults [123]. Maintenance has been described as "the performance of inspection and/or servicing tasks at regular intervals, to retain a product's functional capabilities and/or cosmetic condition" [165]. This can involve repair, which has been defined as "restoring a product to a sound/good condition after decay or damage. After repair, the product is expected to be in a usable state, but assurances of performance are generally limited to the repaired part" [40]. During repair and maintenance, it is important to avoid introducing measures that impede other circular economy strategies, such as disassembly (Section 4.9), reuse (Section 4.4) and remanufacturing (Section 4.7).

Maintenance and repair are often, in part, combined and confused with refurbishment and upgrading $[123,165]$. Refurbishment has more similarities to remanufacturing and will be covered there (Section 4.7). Upgrading-described as "the process of enhancing, relative to the original design specifications" [165] — would arguably be more at par with refurbishing if it constitutes an improvement in functionality, while cosmetic changes could be a part of maintenance and repair.

Repair and maintenance are normal practices in offshore wind, as reflected in the literature with 254 publications on repair and 1274 on maintenance (search in Table 3 and results in Figure 3), the former being almost a complete subset of maintenance. An outward exploration suggests a focus on various parts of the wind infrastructure, costs and risk, and strategies/planning to deliver maintenance and repairs. Alternative searches (Table 3) related to repair and maintenance practices returning significant numbers of results include inspections (247 publications), service (634), O\&M (operations and maintenance) (238) and retrofit (20). A deeper review can determine the alignment of current offshore 
wind repair and maintenance practices with circular economy, and articulate whether any improvements are possible.

\subsection{Component Reuse and Repurposing}

Component reuse constitutes operations through which products or components that are not waste are used again for the same function and may involve "checking, cleaning, repairing, refurbishing, whole items or spare parts" to prepare for reuse $[158,165,166]$. Reuse can be enhanced by durable designs (Section 4.18) and maintenance and repair (Section 4.3) for lifetime extension (Section 4.5) (Figure 2), and it slows down the speed of material flows from production and use to recycling [40]. If a component or product is used for another function, then it would be considered repurposing. For example, using a turbine blade as a blade again would be reuse, whereas using (a section of) a blade to construct a bridge would constitute repurposing (see, e.g., [47,113,167,168]).

Research on reuse is still emerging, with eight of the 32 results from the literature search (Table 3) indeed covering publications on the reuse of offshore wind turbine components (e.g., [43,169-171]) (Figure 3). Various publications explore the reuse of oil and gas platforms for offshore wind (e.g., [172-176]). Some articles write about the reuse of materials, which technically is recycling (Section 4.13). Filtering through the 372 publications on used parts and the eleven on breaking parts may render additional relevant publications. There are only two publications on repurposing (search in Table 3), neither of which are about the repurposing of offshore wind components (Figure 3). There is potential for knowledge exchange with onshore wind where component reuse and repurposing are already more common practice.

\subsection{Lifetime Extension}

Wind farms currently have a designed service life of 20-25 years, when operators have to decide whether to extend the lifetime of assets or to repower (Section 4.6) or decommission (Section 4.11) the site $[177,178]$. These strategies operate at the whole infrastructure level and thereby differ from the most common circular economy strategies, which are generally product-centric (see, e.g., [50,123]).

Lifetime extension means that assets are kept in use beyond the designed service life. Decisions for end-of-use scenarios are formed by a range of technical, economic, environmental and governance aspects, influenced by a range of stakeholders $[178,179]$. The technical aspects include "an exhaustive failure mode identification" for the whole lifecycle of the wind farm [178]. While lifetime extension can increase the return on investments and reduce the levelized cost of electricity, any wins may be cancelled out by higher operation and maintenance costs [178]. From a resource productivity perspective, extending the lifetime of wind farm assets is generally beneficial.

Lifetime extension is likely to include more repairs and maintenance (Section 4.3) and possibly the reuse of components (Section 4.4) that may have been refurbished, upgraded or remanufactured (Section 4.7). The line between lifetime extension and repowering (Section 4.6) is not clearly defined but, through stakeholder discussions, it appears that lifetime extension does not involve the large-scale replacement of components, whereas repowering does.

The scientific literature harbours sixteen publications on offshore wind and lifetime extension (search in Table 3), all of which appear relevant upon scanning the abstracts (Figure 3). The articles primarily discuss structural health monitoring and fatigue assessments [180-193], data systems [194] and decision-making to either extend the lifetime, repower or decommission [195], aligning well with alternative circular economy terminologies suggested during the Offshore Renewable Energy Catapult workshop (Table 2), such as "digital twin" and "residual strength determination". Alternative searches (Table 3) rendering significant results are "fatigue life" (190 publications) and "remaining life" (17), suggesting that these are more common terms than "lifetime extension" within the offshore wind community. An initial exploration suggests that the terms are related but not 
synonymous, with fatigue and remaining life investigating the durability aspects, though not for lifetime extension in particular (e.g., [196-198]). The term "derating" also returned ten search results. A broader search on wind energy returned 62 publications on lifetime extension and 1213 on fatigue life, and these results may hold relevant insights that can be transferred to the marine environment.

\subsection{Repowering}

Repowering has been described as: "A way of extending wind farm's service life by replacing either wind turbine components or existing wind turbines with new, more powerful machines. There are two main types, partial and full repowering" [179]. Partial repowering involves the lifetime extension of some components-e.g., foundations and towers-while others get replaced-e.g., generators, drive trains and blades [178,179,199]. Full repowering involves the replacement of the whole turbine [179]. In all cases, a part of the wind farm infrastructure is reused, such as the subsea cables [178].

The ability to reuse the infrastructure depends on repowering with smaller, similar or larger turbines. Smaller turbines can be attractive if there are concerns about the structural strength of the foundations - which may not be able to carry a similar or larger turbine for a required period-while postponing the decommissioning costs [200]. More common, however, is the repowering with larger turbines, especially in locations with a high wind resource [179].

Repowering decisions are made with regard to the whole wind farm and not at the individual component level. Similar to lifetime extension, it can make use of repaired, reused, refurbished, upgraded and/or remanufactured components, depending on the repowering strategy. Alternatively, components can be sent for repurposing in other sectors or join the recycling and disposal stream.

Repowering is still an emerging subject in offshore wind literature, with the literature searches (Table 3) returning 56 publications, of which 21 bear direct or some relevance (Figure 3). Most articles speak about decision-making approaches literally [179,195] or subjects in relation to decision-making, such as optimisation strategies [201], environmental impacts [202] and techno-economic/cost assessments [178,199,203-205]. Others focus more on lifetime extension [200,206] and decommissioning [177]. "Replanting" (discussed in [8]) and "end-of-life extensions" (Table 3) did not find resonance in the offshore wind literature. There were 280 publications on wind and repowering on Scopus with the potential to transfer expertise from onshore to offshore wind, as the repowering of onshore wind farms is already more widespread (see, e.g., [207-216]).

\subsection{Refurbish and Remanufacture}

Refurbishing and remanufacturing are similar, but the former is less rigorous in nature. Refurbishing has been described as "the overall structure of a large multi-component product remains intact, while many components are replaced or repaired, resulting in an overall 'upgrade' of the product" [123]. Products and components can be designed to accommodate upgrades in the future (Section 4.18) and have been described as "the ability of a product to continue being useful under changing conditions by improving the quality, value, and effectiveness or performance" [40].

Remanufacturing is a process in which components and products are sorted, selected, disassembled, cleaned, inspected and repaired or replaced before being reassembled and tested to function as good as new or better $[217,218]$. Arguably, remanufacturing has to follow a standardised industrial process that is "fully documented" and "capable to fulfil the requirements established by the remanufacturer" (internationally agreed remanufacturing definition from September 2016 [219]).

Remanufacturing is considered more sustainable than manufacturing due to its reduced energy and material requirements, which can be calculated into the price, generally making remanufactured products and components more affordable to customers and profitable for a remanufacturing business [220]. There are benefits for remanufacturers to adopt 
product-service systems (see, e.g., [221]), i.e., selling the function that a component fulfils while the (re)manufacturer keeps ownership of the asset, because it reduces the risk in terms of the timing, quantity and quality of the components returned for remanufacturing, with the economic and environmental benefits rippling through to clients and Original Equipment Manufacturers [222].

Refurbishing $[199,223-226]$ and remanufacturing $[8,227,228]$ are emerging subjects within the offshore wind literature, with only a handful of publications coming forward (Figure 3). Alternative searches (Table 3) that return results include "upgrade" (32 publications) - regularly used, for example, for upgrades to transmission systems (e.g., [229-231]) —and "overhaul" (four publications), while "parts" attracted over a thousand search results, reflecting the generality of the term. There are substantially more publications on wind energy and refurbish (175 publications) and remanufacturing (44,), which may render useful insights for applications in offshore wind.

Refurbishing and remanufacturing are considered closely alongside disassembly (Section 4.9)—a necessary step ahead of remanufacturing and, indeed, other circular economy practices such as repair (Section 4.3), reuse (Section 4.4) and recycling (Section 4.13)-Figure 2.

\subsection{Recertification}

The importance of the reliability of materials and components was raised in conversations with offshore wind experts, and this is also a known challenge in other energy sectors, such as oil and gas. Recertification has been proposed in circular economy as a possible enabler for various strategies (e.g., $[27,232,233]$ ), giving quality assurances about the processes followed, and the quality of reused, repurposed, refurbished and/or remanufactured components (Sections 4.4 and 4.7) and recovered materials (Sections 4.13 and 4.16). Although recertification is neither without challenges nor a silver bullet to all barriers (e.g., [234-236]), it can pre-empt barriers to the uptake of circular economy strategies in offshore wind. Recertification is also important in creating a level playing field internationally, to avoid dynamics such as those observed in metal recycling with illegal exports and rogue operators that undercut quality undertakings and introduce high price dynamics that constrain investment [232]. Recertification is closely related to reliability testing [27], a concept that finds resonance within the offshore wind literature (e.g., $[237,238])$.

Searching for publications on recertification in offshore wind (Table 3) rendered no results (Figure 3), but a search for certification returned twelve publications (e.g., [239-241]). For wind energy in general, there were nine articles mentioning recertification, none of which look particularly relevant with regard to the considerations outlined above, and over a thousand publications about certification.

\subsection{Disassembly}

Disassembly plays a key part in the repair (Section 4.3), reuse (Section 4.4), remanufacturing (Section 4.7) and recycling (Section 4.13) of components, and all can benefit from the consideration of disassembly at the component design stage (Section 4.18) [242]. Disassembly is a highly specialised activity [243] which can benefit from and generate detailed data on the resource volumes and qualitative characteristics (covered in Section 4.17) necessary to enable a circular economy for low-carbon infrastructure [66].

Disassembly is also intricately linked to decisions about the end-of-use strategy [244], and the demand for saving components to reuse, remanufacture, etc. for usage in lifetime extension (Section 4.5) or repowering (Section 4.6). Decisions on end-of-use can be made before, during and after disassembly, deciding whether a (part of a) component can be repaired, reused or remanufactured or should be sent to recycling or disposal [244]. Components can be fully or partially disassembled, but generally they are fully taken apart because the value of recovered parts outweighs the disassembly cost, and it is usually more time-efficient $[243,244]$. 
Disassembly is also important for high-value recycling, as it enables the better segregation and recovery of material streams with less contamination when compared to, for example, the crushing and milling of whole components or structures [245]. Here, too, design for disassembly can help to enable the closing of resource flows (Section 4.18).

Disassembly is not widely investigated in offshore wind research, with only two publications emerging [246] (Figure 3). There is a high potential for knowledge exchange across the wind sector, with 99 search results on disassembly.

\subsection{Modularisation}

Disassembly (Section 4.9) to enable repairs (Section 4.3), reuse (Section 4.4) and remanufacturing (Section 4.7) can be eased by the modular design of components (Figure 2). Modular design enables the decoupling of the component lifetime from the lifecycle of a wind turbine (thereby enabling lifetime extension, Section 4.5), avoiding the wastage of the remaining lifetime of components that are still safely operational [247]. Modular design includes the avoidance of irreversibly joining together different materials and components, especially when they have different forecast lifetimes, a preference for using common modules that can be reused and that are easy to repair and upgrade, the ease of quality assurance and, possibly, the inclusion of quality monitoring devices [247-250].

Modularisation and modular design are known strategies within offshore wind but, so far, have not been considered within the context of a circular economy (Figure 3). Scopus did reveal six publications on modularisation or modular designs, half of which appeared to hold relevance [251-253], though there were 189 search results for wind modularisation in general. A deeper search better demonstrated the relevance to circular economy, covering subjects such as easing repair and operations and maintenance [253,254], adaptability of components [255], improving quality and performance [252,256], reducing costs [257] and enabling the manufacturing and transport of very large components [258].

\subsection{Decommissioning}

Decommissioning has been described as "de-energising and removing wind farm infrastructure", in which de-energising involves the disconnecting of the wind turbines and/or whole farm from power transmission [259]. The standardisation of decommissioning is expected to be limited due to the technical diversity of offshore wind farms, weather conditions and site-specific conditions [199]. Smith and Lamont [260] defined three stages in decommissioning processes consisting of the "preliminary work to develop detailed plans and permits; then an operational phase to remove the turbines and their foundations, and to address other offshore structures and cables; and finally a monitoring phase".

Experience with offshore wind decommissioning is limited and lacks clear practical guidelines $[177,260]$. It is often depicted as reverse engineering requiring similar techniques, equipment and skills [199]; however, early signals suggest that the process is more complex, especially with the aim of maximising resource productivity $[8,66]$. Perspectives on the endof-use management of decommissioned components are often limited to "waste treatments" that are "divided into recycling, landfilling, and incineration" [178], leaving the broader set of economically, socially and environmentally more valuable circular economy strategies such as reuse (Section 4.4) and remanufacturing (Section 4.7) out of sight. This is not aided by underdeveloped regulations [177] that, moreover, fail to take a proactive approach to salvage components before the formal seize of operations, and lump component reuse and material recycling into one category [8].

Jensen et al. [8] argue for a proactive approach, taking a whole system perspective to design offshore wind farms with decommissioning in mind. Similarly, Smith and Lamont [260] argue for the design of large components that can be broken into parts. Early experiences suggest that downsizing large components into smaller parts that can be processed further is challenging. Such design considerations must be made while being mindful of the interface between decommissioning, disassembly, and the potential to 
maximise the value generated from components and materials using the full spectrum of circular economy strategies (Figure 2).

The decommissioning of offshore wind farms can be partial or in full. Partial decommissioning involves the dismantling of the components except for those that have a longer designed service life, such as foundations and inter-arrays and export cables [199], combined with repowering (Section 4.7). Full decommissioning involves, in principle, the removal of all infrastructure, the objective of which is, arguably, "to return the site to its condition before project deployment as far as possible" (Section 4.12) [199].

Offshore wind decommissioning is a growing subject area, with 112 publications (search in Table 3), of which 86 hold direct or some relevance to offshore wind (Figure 3). Subjects covered include estimating the scale of the decommissioning challenges (aided by articles such as [60,261,262]); cost models and decommissioning scenarios (e.g., [171,200,204,263-273]); decommissioning processes; challenges and solutions $[8,141,177,274,275]$; vessels and port facilities (e.g., [276]); end-of-use scenarios (e.g., $[195,277,278]$ ); risk, durability and the remaining life estimates (e.g., [279-281]); alternative joints to ease decommissioning [282]; environmental impacts (e.g., [283-286]); and calls for better policy, guidelines and certification (e.g., [8,287-289]). Alternative searches (Table 3) to explore further include removal (72 publications), extraction (187) and dismantling (21). Trawling through the 355 search results on decommissioning and wind energy in general may also return useful further insights for offshore wind.

\subsection{Site Recovery}

Returning sites to a similar state as before wind farm development is inherently integrated with decommissioning (Section 4.11). In principle, in the North Sea, full decommissioning and site recovery is obligatory under international agreements. However, given that offshore wind farms tend to have been developed in locations with high wind resources, full decommissioning and site recovery may not be a strategy often taken within the next few decades. So far, sites were fully decommissioned due to seabed instability or being demonstration/research projects [260], or due to being located closer to shore with limitations for upscaling through repowering (Section 4.6).

Similar to debates in oil and gas with regard to rigs-to-reefs (e.g., [290-292]), in offshore wind, there is a discussion about whether the complete removal of concrete structures is the best environmental option due to the potential to function as artificial reefs $[199,293,294]$. In the recovery of sites, as in every step of the wind farm lifecycle, consideration should be given to other users of the marine space, such as nature conservation, fishing, shipping and defence $[124,134]$.

Within the offshore wind literature, no articles surfaced on site recovery or site restoration (search in Table 3 and results in Figure 3). Habitat restoration returned two publications [295,296]. Artificial reefs as an alternative search (Table 3 ) had 52 search results worth investigating further.

\subsection{Recycle Materials}

The recycling of materials is not clearly defined in the waste hierarchy, being described as "any operation the principal result of which is waste serving a useful purpose by replacing other materials which would otherwise have been used to fulfil a particular function, or waste being prepared to fulfil that function, in the plant or in the wider economy" [297]. DEFRA [158] described it as "turning waste into a new substance or product", displaying ambiguity about what constitutes recycling: just the collection and preparation of wastes into materials that can re-enter production, or must it be followed by reprocessing into new products? Den Hollander et al. [165] argued that "the recycling process involves the dismantling and disintegration of a product and its constituent components and the subsequent reprocessing of the product's materials". Recycled materials are also known as secondary resources, differing from primary resources that were sourced directly from the natural environment. Recycling is the only circular economy strategy that is truly about 
"closing loops" of material flows within the economy [40]. Recycling is often confused with reuse-implying the reuse of materials-and it is therefore distinguished herein by material recycling and component reuse (Section 4.4).

There are 42 publications on offshore wind and recycling (search in Table 3), 27 of which look relevant (Figure 3). Many studies present lifecycle assessments, emphasising how recycling can reduce the environmental impacts of offshore wind [298-304]. Others discuss the selecting of recyclable materials [287] and the use of recyclates [43,305,306]. Further articles offer insight into recycling processes, technologies and the costs and value of recycling $[5,48,59,307]$. More knowledge about the recycling of wind turbine components could be found by broadening the scope to wind energy in general (1675 search results) and by focusing on specific components and materials. Note, for example, the growing body of literature on blade recycling, which remains problematic (see, e.g., [308,309] and publications with recent cross-sectoral reviews of relevant composite recycling technologies, e.g., $[8,64,310])$. Regarding the materials in general, there are more than 8,000 publications on steel recycling, over 12,000 on concrete recycling (but do note that the recycling of concrete from the marine environment differs from the terrestrial environment), 65 on glass fibre reinforced composite recycling and 151 on the recycling of critical materials.

\subsection{Energy Recovery}

Energy "recovery" refers to the recovery of the energetic input invested into the preparation of materials, components and products. Recovery is often confusingly used for both the recovery of materials (technically recycling, Section 4.13) and energy [123,311]. Energy recovery can include the capturing of heat, gas, power or a combination of these, generally from thermal treatments of wastes but, also, biological treatments [312]. DEFRA [158] captures energy recovery under the broader banner of "other recovery", including "anaerobic digestion, incineration with energy recovery, gasification and pyrolysis which produce energy (fuels, heat and power) and materials from waste". Thermal energy recovery processes are commonly described as energy-from-waste and considered a less preferable strategy within a circular economy due to the loss of the quantities and qualities of materials. Incineration without energy recovery is considered disposal, similar to landfilling [158]. It is possible to recover some materials from energy-from-waste ashes.

There are thirteen publications mentioning energy recovery and offshore wind (search in Table 3), only one of which discussed energy recovery in the context of offshore wind end-of-use management [8] (Figure 3). Three further publications on energy-from-waste (alterative search Table 3) do not discuss the processing of wind turbine components. A similar fate goes to the affiliated terms such as incineration, burning, gasification and thermal treatment. More relevant results may emerge in the 318 search results when broadening to wind in general (e.g., $[310,313,314])$.

\subsection{Landfill and Controlled Storage}

Landfills are used for disposing solid wastes. Landfills can be "open or uncontrolled dumps" with "immediate risks to human health and the environment" [315]. However, in developed countries, landfills are, generally speaking, engineered sites in which solid wastes are placed and compacted into defined cells, in lined systems to prevent leachate (a liquid of water that has been in contact with waste) from polluting the surrounding water sources, that are regularly covered with soil during the filling operations to prevent fires and air pollution, and capped once the landfill cell is full [315]. Landfills are increasingly integrated with materials and energy recovery systems. Landfill gas-primarily methanecan be captured and converted into heat or power. Resources can be recovered with the use of bio-related technologies that enable re-mining (Section 4.16) [316,317].

There are seven articles on Scopus on offshore wind and landfills (search in Table 3), of which only one article holds some relevance [318] (Figure 3). Additional and alternative searches (Table 3) such as controlled storage and burial/burying did not deliver relevant 
results. A broader search for wind and the landfilling of waste may offer starting points leading to further insights (e.g., $[49,94,319,320])$.

\subsection{Re-Mine}

Re-mining is the recovery of materials from "Anthropogenic Ores": the industrial, municipal, metallurgical and mining wastes that people have entrusted into geological storage [317]. Landfill/urban/secondary mining is receiving growing attention [316,317]. This is, in part, due to the need to clear away legacy wastes and mitigate risks due to landfill degradation, environmental change, pressure on land availability and resource scarcity. Landfills contain considerable resource stocks of materials that are essential for low-carbon infrastructure [321]. Elements such as copper (e.g., for cables), cobalt (e.g., for generators) and vanadium (e.g., in alloy steel for towers) can be re-mined from landfills [316]. Moreover, "landfills" can be engineered specifically for the recovery of target materials [317,322]. While landfilling and mining tend to fall outside of the scope of circular economy thinking, there is much to win from applying circular economy approaches in these sectors due to the high volumes of waste involved and the presence of increasingly scarce materials for low-carbon infrastructure [41,42]. The recovery of valuable yet potentially harmful substances from landfills is also important to enable the safe reintegration of organic and inorganic resources into natural biogeochemical cycles [41].

Re-mining is a new concept to offshore wind with no publications yet (Figure 3), and one publication when searching for wind in general which was unfortunately not relevant. Urban mining is more commonly used, with three relevant articles for the wind sector [323-325] and much more potential when searching at the material level of urban mining (e.g., copper, rare earth elements, etc.).

\subsection{Data and Information}

Insights into the volumes, qualitative technical characteristics and associated environmental, social and economic values are crucial in enabling a more circular economy, because such information is necessary for decision-making by governmental bodies, as well as companies, with regard to the uptake of circular economy practices (see, e.g., [139,326]). A company will want to ensure that sufficient volumes of materials are available before committing to specific designs, such as using electromagnetics instead of permanent magnet solutions to alleviate the competition for critical materials [327]. Governments will want to manage geopolitical dynamics around accessing critical materials necessary for low-carbon transitions. Manufacturers need to have assurances about the component and material qualities to enable reuse (Section 4.4), remanufacturing (Section 4.7), recycling (Section 4.13), etc. based on accurate information that can be verified and certified (Section 4.8).

There are many sides to developing data and information strategies to enable circular practices in offshore wind. These include, but are not limited to: the design and management of data systems themselves; the provision, linking, storing, converting and sharing of datasets; standards to guide all aspects of data collection, sharing, etc.; a relevant set of indicators about which the data will be collected; and sensors and other measuring equipment and infrastructure to collect data. Chen et al. [60] offer a recent overview of research on waste generation forecasts, primary and secondary material flows, and component stocks. Lifecycle assessments are common practice within offshore wind, meeting a part of the demand for data and information to enable decision-making about circular practices.

Literature searches (Table 3) have demonstrated that research on the various aspects of data and information systems are underway in offshore wind, but it is not immediately clear that an integrated holistic system, as described above, is available or under development (Figure 3). Zhao et al. [328] propose the combining of SCADA (Supervisory Control and Data Acquisition) and CMS (Condition Monitoring System) models to assess drivetrain degradation, and Cheng et al. [329] develop a multi-model industrial big data benchmark involving the bill of materials for wind infrastructure, which may form a stepping stone 
towards an integrated holistic data system for the diverse values of materials, products and components.

Alternative searches (Table 3) return 60 publications on lifecycle and data, confirming the regular use of lifecycle assessments. Sustainability assessments only return eleven search results, implying this may be a less common practice in the sector. Nevertheless, sustainability and indicators show some relevant results (e.g., [330,331]). Nothing has been published in the scientific literature on data standards in offshore wind, although this could easily have been captured under an alternative search term. Data sharing has been raised (e.g., [332,333]). The progress made for this circular economy strategy is very fuzzy to assess, with many aspects of data and information systems that need to be brought together deserving a deeper review, which would likely result in a more positive assessment of the state of play in offshore wind (Figure 3).

\subsection{Design for Circularity}

The art of designing for circularity is to design products, components and whole infrastructure in such a way that it maximises the sustainability potential of a circular economy with a balanced mix of the strategies included above (Sections 4.1-4.17, Figure 2). The design for a circular economy has to be proactive, as Andrews [156] said: "Designers cannot wait for the development of a remanufacturing, reuse and/or recycling infrastructure and other alternative business models, however, before they start to design for the Circular Economy; they must anticipate and prepare for the alternative economy particularly where there is a long product lead time from initial concept to shop floor". Indeed, it is important to consider circular economy early on in the design process, "because once product specifications are being made, only minor changes are usually possible" [40]. None of the circular economy strategies should be considered in isolation, enabling strategies to narrow, slow, close and integrate resource flows $[40,41,155,334,335]$ throughout the lifecycle of materials, products, components and infrastructure (Figure 2).

Design for circularity differs from eco-design. Eco-design is described as a practice to make the current poor environmental performance of products and components less bad throughout their lifecycles $[165,336]$, i.e., incrementally improving the existing situation. Although design for circular economy takes a similar whole lifecycle perspective, it arguably differs by starting from the perspective of an ideal vision and taking a back-casting approach to design products and components in a radically more environmentally benign way $[165,337]$. It has been demonstrated, however, that there are circular economists that take a reformative view (staying close to the status quo, arguably staying closer to ecodesign practices), while others are more transformative in their ideas (radically changing the current practices) [123].

There are more than 5000 publications on Scopus (search in Table 3) about offshore wind and design and, after narrowing the search results to "circular economy", only one covers designing offshore wind with a circular economy in mind [8] (Figure 3). An alternative search on holistic design (Table 3) returns relevant search results, for example, in terms of the potential to reduce material use, i.e., dematerialisation (Section 4.1) (e.g., [338-340]) and the incorporation of a broader set of whole system sustainability considerations (e.g., [341-344]). The alternative "integrated design" is more about the approach towards testing whole units of wind infrastructure as one system (e.g., [345]). A closer inspection of this large body of literature on offshore wind design is necessary to determine the current alignment with circular economy principles and to identify more targeted opportunities for improvement.

\section{Discussion: Application and Transferability of the Framework}

\subsection{How to Use the Framework}

Circular economy is a whole system and whole lifecycle approach and therefore all strategies are important to consider in conjunction with each other (Figure 2). In principle, the strategies at the top of Figure 2 have a greater sustainability potential than the strategies 
nearer to the bottom. For example, decisions made at the design stage will greatly affect the potential for component reuse, lifetime extension, the repowering of whole sites, etc. There may be trade-offs between durability - with strategies such as maintenance and repair, reuse and repurposing and lifetime extension—and recyclability. Strategies focusing on durability generally have a higher potential to increase resource productivity and to reduce environmental impacts, but in the long term, resource security may be best served with access to high-quality recycled materials. At this point, it is not clear yet whether these strategies can work in synergy or whether trade-offs should be anticipated for some or all of the components in offshore wind. The steel in towers, for example, is not a particular concern with regard to resource security, and the design for durability-by adding more concrete to the tower-can substantially increase the longevity and has a far greater potential for reducing environmental impacts than steel recycling alone [7]. Conversely, neodymium used in permanent magnet generators is a critical material due to geopolitically motivated resource access risks, and long-term access may depend on high-quality recycling but, currently, the recycling rates are very low, and the potential use of recyclate in offshore wind also appears limited [97]. Finally, the application of the framework is pragmatic. For example, it is too late for strategies such as design for circularity for turbines that are already in the water, but for wind farms early in the development phase this is still a possibility.

It would be unrealistic to act as if the offshore wind sector is starting from a blank canvas. This sector is in the process of moving from industrial exploration to exploitation with the dominating three-blade rotor design, with strong growth ambitions that, as introduced in Section 2.2, raise a number of circular economy-related sustainability challenges and opportunities. Figure 4 depicts the top three circular economy strategies to help getting to grips with each of the sustainability challenges, but further circular economy strategies may apply as well. Speaking through each of the challenges:

In an effort to reduce fossil fuel reliance, the primary aim should be to design out fossil-based materials, but, if impossible, the usage should be minimised and, given the reliance on a non-renewable resource, ensuring recyclability should then take priority. There is an interdependence between the challenge of designing out fossil-based materials and the opportunity of material innovation (discussed next).

Growing resource exploitation, resource competition and material innovation are clustered together, because they form closely related challenges and opportunities. Resource exploitation and competition imply that it may become more difficult to access sufficient volumes of resources in a sustainable manner to meet the sector's growth ambitions, and, in response, solutions are being sought via material innovation. In the short term, the challenge could be met by minimising the volumes of materials that are difficult to obtain and to search for alternative sources of increasingly critical raw materials, such as re-mining landfills. In the medium-term, alternative materials may become available for the design and manufacturing of components. For long-term resource security, it is important to design for recyclability and to improve the usage of recycled materials-such as recovered rare earth elements-in offshore wind component manufacturing, which may be aided by recertifying the secondary resources supported by transparent data and information systems about resource stocks and flows.

The durability and lifetime extension of the existing stock of offshore wind infrastructure is best aided by maintenance and repair to keep all the components in a good state, thereby enabling safe lifetime extension of the infrastructure. As argued in Section 2.2, this could be supported by remote monitoring, digital twin models and data systems. Lifetime extension may increase the potential for direct component reuse within the offshore wind sector, with greater environmental benefits when compared to repowering with new and larger components. At a whole system level, however, this strategy would have to be weighed against the environmental benefits of the growing renewable energy capacity through repowering. 
End-of-use management and sustainable decommissioning are clustered, because they are closely related. Decommissioning and disassembly should be done in such a way that the components can either be reused, repurposed, refurbished, remanufactured or taken apart further to enable material segregation followed by high-quality recycling. The recertification of components and materials can help in creating new markets, unlocking investment into sustainable end-of-use supply chains, backed up by data and information systems through which the availability of volumes of materials and their technical characteristics can be assured. Experiences with end-of-use management should feed back into the design stage to grow the expertise in design for circularity, including the design for sustainable decommissioning and end-of-use management.

The framework is not the answer to all sustainability challenges and opportunities as indicated by the energy use challenge not being connected to a particular circular economy strategy. Reducing energy use falls outside the scope of the design, development, operating and end-of-use management of offshore wind infrastructure for which the circular economy framework was developed. Nevertheless, it is an important challenge to become involved in as part of the broader low-carbon and sustainable transition, for example, via the delivery of corporate social responsibility policies.

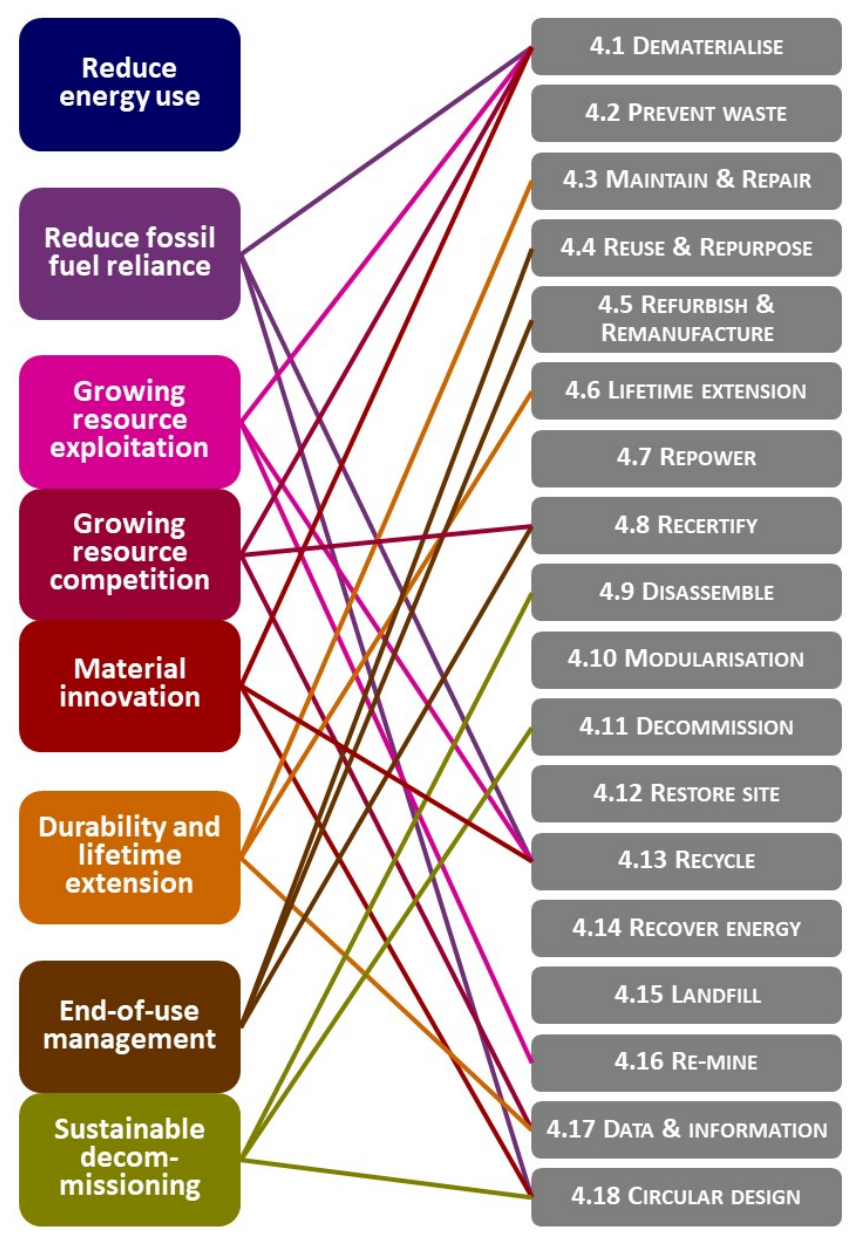

Figure 4. Top three circular economy strategies (on the right, as introduced in Section 4) in response to circular economy-related sustainability challenges and opportunities (on the left, as introduced in Section 2.2).

\subsection{Transferability to Other Sectors}

\subsubsection{Circular Economy Frameworks across Energy Industries}

This section will discuss that circular economy is an emerging subject in the scientific literature on energy infrastructure, and the presented framework could add value more 
broadly beyond offshore wind. A Scopus search on 7 June 2021 revealed just six publications mentioning energy infrastructure and circular economy in their article title, abstract or keywords [9,247,346-349]: Moore et al. [348] analyse how electric vehicle batteries could have a second life as emergency back-up power storage, while Fogarassy et al. [347] explore the circularity of solar power infrastructure for large-scale events, and Mignacca et al. [247] focus primarily on the modularisation of oil and gas infrastructure to enable a more circular economy. Overarching studies cover the circularity of China's infrastructure [346] and how circular economy can function as a positive driver to increase project performance in energy infrastructure decommissioning [9]. Kouloumpis and Yan [349] present and pilot a tool for the participatory lifecycle assessment of small island energy scenarios. Given that none of these publications include a comprehensive circular economy framework, the framework presented herein could potentially also add value to other energy sectors.

Investigating the presence of circular economy frameworks in specific energy sectors offers further insights. Niccolini, et al. [350] recognise circular economy as a means to reduce costs throughout oil and gas infrastructure project lifecycles. No articles were identified that systematically apply circular economy to the management of nuclear energy infrastructure. In low-carbon infrastructure, circular economy represents a new subject area with three articles currently published, all taking a holistic perspective on interconnected infrastructure systems $[8,351,352]$. Frameworks for circular economy and renewable energy are more common, with Scopus returning 62 publications. However, only six articles carry a potential relevance upon scanning the titles and abstracts [353-358]. Klemeš et al. [355] offer an overview of circular economy and sustainability in the context of energy systems, covering resource recovery, sustainability indicators, air pollution, and energy system optimisation for cooling, heating and power generation. Abokersh et al. [358] develop a set of Sustainable Circular System Design indicators, including a product Material Circularity Index and an Environmental Sustainability and Circularity indicator, for the sustainability assessment of geothermal storage in a circular economy context. Taking a transition perspective, Kylili et al. [357] share a holistic approach for sustainable renewable energy developments, including circular economy approaches in the form of lifecycle assessments and more sustainable management of waste biomass. Salim et al. [353] propose a framework of barriers, drivers and enablers for the solar PV sector to transition towards greater circularity, and Chen and Kim [354] compare the circular economy and energy transition contexts and argue for the non-energy use of fuels as a bridge to integrate them better. Searching for circular economy frameworks in photovoltaic systems specifically reveals the article by Contreras-Lisperguer, et al. [359], developing a model to forecast material flows in support of the recycling of solar technologies.

Aguilar Esteva et al. [356] propose a circular economy framework closely resembling the style of the framework presented herein, though for automobiles and at the product level, which excludes the necessary infrastructure level strategies for circularity in offshore wind. Similar strategies for the material and product levels are included, covering three lifecycle stages: materials and manufacturing (material sourcing, product design, automotive manufacturing and supply chain logistics); use (fuel economy, fuel type and powertrain, servicing incl. refuelling, cleaning, maintenance, repair and remanufacturing) and end-oflife (dismantling, remanufacturing, parts reuse and material recycling). Strategies such as material sourcing, logistics and powertrain design could be interesting to bottom out more for offshore wind as well.

\subsubsection{Application of Offshore Wind Circular Economy Framework in Other Sectors}

The circular economy framework can be applied to other sectors, but the emphasis of strategies may differ due to their industrial lifecycle stage-i.e., whether a sector is generally exploring or exploiting practices-within the energy transition. Exploration involves radical innovation and a searching for the reason, or function, for an industry to exist, while exploitation involves incremental innovation and a focus on the efficiency of delivery of an industry's function [360-363]. For example, given the steady growth and 
stabilising practices, fixed bottom offshore wind with the domineering three-blade rotor design could be seen as entering exploitation. Circular economy strategies for offshore wind are the most likely to offer opportunities for transferability to oil and gas due to the infrastructure located in the marine environment, and to onshore wind due to the technological similarities.

Onshore wind has been in exploitation for longer and, reaching end-of-use of the first generation of onshore wind farms in many locations, may be entering a mild exploration phase to reinvent itself as a more multifaceted industry combining additional functions on wind farms such as energy storage-some have suggested this could be another circular economy strategy titled "retasking" (term coined at EoLIS 2020). With regulatory uncertainty regarding repowering currently hanging over onshore wind, lifetime extension is often preferred as a strategy.

Oil and gas should, arguably, be in a deeper exploration phase [364], having to reinvent itself as a more general energy sector for companies to survive. Although the energy transition is gaining momentum, new oil and gas infrastructure is still being commissioned. These should be designed with the energy transition in mind, to enable oil and gas infrastructure repurposing for-and integrating with—sustainable energy systems, for example, using infrastructure for blue and green hydrogen, carbon capture and storage and offshore wind (as suggested by stakeholders, see [365]). In other words, in the case of oil and gas, the lifetime extension of infrastructure for the purpose of extracting fossil fuels should not be strived for, and instead the repurposing of components and whole sites should take centre stage.

The framework could also be applied to other energy sectors, such as biogas, solar energy and energy storage. These types of infrastructure are generally more distributed than wind energy, and this can have implications for the feasibility of circular economy strategies such as maintenance and repair, reuse and remanufacturing-depending on the local skills availability and logistics. Conversely, smaller units of operation, such as solar panels and batteries, may be easier to replace than the large components used in onshore and offshore wind, which could benefit the uptake of circular economy strategies.

Lastly, circular economy requires a cross-sectoral perspective, recognising that the potential for one sector to become more circular is dependent on actions in other sectors. For example, the potential for circular economy in offshore wind could be strengthened by sustainable recycling solutions implemented by the resources, steel and composites sectors. The oil and gas sector explored the potential to repurpose infrastructure for offshore wind (e.g., [366,367]). Offshore wind, in turn, could possibly increase the circularity in onshore wind by reusing decommissioned components for the repowering of onshore wind farms. There are many more of such potential solutions, opening opportunities for sustainability and for new business activities.

\section{Conclusions and Future Perspectives}

In this article, a whole system and whole lifecycle framework was proposed for the integration of a sustainable circular economy into the offshore wind sector, thereby also making an original contribution to the circular economy literature by defining infrastructure level strategies (Section 4). Circular economy-related sustainability challenges and opportunities (Section 2.2) can only be addressed effectively with a holistic approach, such as enabled by the framework, to avoid trade-offs and make the most of synergies (Section 5.1). Moreover, there is a high potential to transfer the framework to other energy sectors and to identify cross-sectoral synergies as well (Section 5.2).

The next steps in the development and uptake of circular economy in offshore wind must include a deeper baseline assessment of the current practices via literature reviews and roundtable discussions with industry practitioners on the various circular economy strategies, including knowledge exchange with onshore wind. Such discussions will also be informative to gain insights into the barriers and enablers for a more circular economy in offshore wind. Figure 3 suggests that the majority of circular economy strategies are 
deeply under-researched in offshore wind and, if an in-depth baseline assessment indeed confirms this is the case, this opens a high demand for fundamental and applied research.

A more thorough baseline review will also provide the foundations for the coproduction of circular economy whole lifecycle scenarios. Such scenarios should then be subjected to the holistic sustainability assessments of social, environmental and economic costs and benefits throughout the offshore wind infrastructure lifecycle (e.g., [368]). Sustainability assessments tend to be data hungry, highlighting the need for the development of data systems and collaborative arrangements to share data on resource stocks and flows into, through and out of the offshore wind sector, which will also give better insight into the scale of challenges and opportunities in terms of the volumes and qualities of components and materials.

Circular economy scenarios for offshore wind are inherently linked to their capability in related sectors (Section 5.2.2). For example, the ability to decommission components in one piece, to enable reuse, repurposing, refurbishing and remanufacturing, depends on the capabilities in the decommissioning and removal sector as well as port facilities; remanufacturing depends on the capabilities of Original Equipment Manufacturers and/or specialist remanufacturing businesses; and recycling depends on the capabilities in the resources sector as well as the resources demand in manufacturing sectors. Developing a circular economy in offshore wind will therefore require a multisector perspective and approach, with business opportunities emerging within and outside of the offshore wind sector. This can open chances to grow or develop local supply chains, often subject to political debate, while reducing the risk for offshore wind, e.g., in terms of sourcing materials to sustain growth ambitions and finding markets for recyclates.

Regional and national capabilities with regard to the various circular economy strategies will influence the feasibility of whole lifecycle scenarios. For example, if the capacity for operations and maintenance is low, then a heavy reliance on maintenance and repair could not be recommended; conversely, when the decommissioning, disassembly and / or recycling capabilities are underdeveloped, then an initial heavier focus on maintenance and repair to increase the chances for lifetime extension would offer the best chance to grow circularity in the short term. The offshore wind sector needs a decision support tool for whole lifecycle scenarios to help determine which strategies are best under which conditions. The conditions may vary across countries due to the differences in legal obligations, and a decision support tool must be coproduced with government and industry representatives.

Finally, the proposed circular economy framework can increase the sustainability of the management of offshore wind infrastructure but, as pointed out in Section 5.1, it is not a silver bullet to all sustainability challenges and opportunities. The integration of the offshore wind sector into discussions on low-carbon and sustainable transitions will require a broader engagement and partnerships beyond the material aspects of growing offshore wind.

Funding: The "A Sustainable Circular Economy for Offshore Wind" project was funded by the EPSRC impact acceleration account awarded to the University of Leeds (EP/R511717/1); co-funded by the Offshore Renewable Energy Catapult and the Department for International Trade to build upon the grants for Undermining Infrastructure (EP/J005576/1) and Infrastructure Business models, valuation and Innovation for Local Delivery" (EP/K012398/1) and, also, the Resource Recovery from Waste programme (funded via NE/L014149/1), the National Centre for Infrastructure Materials (EP/P017169/1) and Leeds' ESRC impact acceleration account (ES/T501955/1) project on circular oil and gas decommissioning. The APC was funded by the University of Leeds.

Institutional Review Board Statement: Not applicable.

Informed Consent Statement: Not applicable.

Acknowledgments: I am grateful for the collaboration of the Offshore Renewable Energy Catapult, the Department for International Trade, CIWM, Ofgem, DTU, HSSMI and all who offered questions and comments in response to publications and at events where the draft framework was presented and discussed, and would like to thank my colleagues at the University of Leeds, in particular Phil 
Purnell, Paul Jensen and Leon Black for their reviews of earlier drafts of this publication. I am also grateful for the feedback from the editors and reviewers who helped to strengthen the manuscript.

Conflicts of Interest: The author declares no conflict of interest.

\section{References}

1. UN. Paris Agreement; UN: New York, NY, USA, 2015.

2. GWEC. Global Wind Report 2021; GWEC: Brussel, Belgium, 2021.

3. IRENA. Global Renewables Outlook: Energy Transformation 2050; IRENA: Abu Dhabi, United Arab Emirates, 2020.

4. Vidal, O.; Goffé, B.; Arndt, N.T. Metals for a low-carbon society. Nat. Geosci. 2013, 6, 894-896. [CrossRef]

5. Topham, E.; McMillan, D.; Bradley, S.; Hart, E. Recycling offshore wind farms at decommissioning stage. Energy Policy 2019, 129, 698-709. [CrossRef]

6. Stamford, L.; Azapagic, A. Life cycle sustainability assessment of electricity options for the UK. Int. J. Energy Res. 2012, 36, 1263-1290. [CrossRef]

7. Gallagher, J.; Basu, B.; Browne, M.; Kenna, A.; McCormack, S.; Pilla, F.; Styles, D. Adapting Stand-Alone Renewable Energy Technologies for the Circular Economy through Eco-Design and Recycling. J. Ind. Ecol. 2019, 23, 133-140. [CrossRef]

8. Jensen, P.D.; Purnell, P.; Velenturf, A.P.M. Highlighting the need to embed circular economy in low carbon infrastructure decommissioning: The case of offshore wind. Sustain. Prod. Consum. 2020, 24, 266-280. [CrossRef]

9. Invernizzi, D.C.; Locatelli, G.; Velenturf, A.P.M.; Love, P.E.; Purnell, P.; Brookes, N.J. Developing policies for the end-of-life of energy infrastructure: Coming to terms with the challenges of decommissioning. Energy Policy 2020, 144, 111677. [CrossRef]

10. Velenturf, A.P.M.; Purnell, P. Principles for a sustainable circular economy. Sustain. Prod. Consum. 2021, 27, 1437-1457. [CrossRef]

11. Ghisellini, P.; Cialani, C.; Ulgiati, S. A Review on Circular Economy: The Expected Transition to a Balanced Interplay of Environmental and Economic Systems. J. Clean. Prod. 2016, 114, 11-32. [CrossRef]

12. Almeida, C.M.V.B.; Agostinho, F.; Huisingh, D.; Giannetti, B.F. Cleaner Production towards a sustainable transition. J. Clean. Prod. 2017, 142, 1-7. [CrossRef]

13. Ashford, N.A. Reflections on the First Decade of the Journal of Cleaner Production. J. Clean. Prod. 2002, 10, 101-102. [CrossRef]

14. Barnard, F. Education for management conceived as a study of industrial ecology. Vocat. Asp. Educ. 1963, 15, 22-26. [CrossRef]

15. Jelinski, L.W.; Graedel, T.E.; Laudise, R.A.; McCall, D.W.; Patel, C.K. Industrial ecology: Concepts and approaches. Proc. Natl. Acad. Sci. USA 1992, 89, 793-797. [CrossRef] [PubMed]

16. Wallner, H.P.; Narodoslawsky, M. The concept of sustainable islands: Cleaner production, industrial ecology and the network paradigm as preconditions for regional sustainable development. J. Clean. Prod. 1994, 2, 167-171. [CrossRef]

17. Gibbs, D.; Deutz, P. Reflections on implementing industrial ecology through eco-industrial park development. J. Clean. Prod. 2007, 15, 1683-1695. [CrossRef]

18. Jensen, P.D.; Basson, L.; Leach, M. Reinterpreting Industrial Ecology. J. Ind. Ecol. 2011, 15, 680-692. [CrossRef]

19. Johnson, D.G. Resource Efficiency and Policy. J. Farm Econ. 1950, 32, 123-128. [CrossRef]

20. Duflou, J.R.; Sutherland, J.; Dornfeld, D.; Herrmann, C.; Jeswiet, J.; Kara, S.; Hauschild, M.Z.; Kellens, K. Towards energy and resource efficient manufacturing: A processes and systems approach. CIRP Ann. Manuf. Technol. 2012, 61, 587-609. [CrossRef]

21. Allwood, J.M. Unrealistic techno-optimism is holding back progress on resource efficiency. Nat. Mater. 2018, 17, 1050-1051. [CrossRef]

22. McDonough, W.; Braungart, M. Towards a sustaining architecture for the 21st century: The promise of cradle-to-cradle design. Ind. Environ. 2003, 26, 13-16.

23. Stahel, W.; Reday-Mulvey, G. Jobs for Tomorrow, the Potential for Substituting Manpower for Energy; Vantage Press: New York, NY, USA, 1981.

24. Cole, R.J. Transitioning from green to regenerative design. Build. Res. Inf. 2012, 40, 39-53. [CrossRef]

25. Roy, R. Sustainable product-service systems. Futures 2000, 32, 289-299. [CrossRef]

26. Mont, O. Clarifying the concept of product-service system. J. Clean. Prod. 2002, 10, 237-245. [CrossRef]

27. Tsanakas, J.A.; Van Der Heide, A.; Radavičius, T.; Denafas, J.; Lemaire, E.; Wang, K.; Poortmans, J.; Voroshazi, E. Towards a circular supply chain for PV modules: Review of today's challenges in PV recycling, refurbishment and re-certification. Prog. Photovolt. Res. Appl. 2020, 28, 454-464. [CrossRef]

28. Da Costa Fernandes, S.; Pigosso, D.C.; McAloone, T.C.; Rozenfeld, H. Towards product-service system oriented to circular economy: A systematic review of value proposition design approaches. J. Clean. Prod. 2020, 257, 120507. [CrossRef]

29. Pearce, D. Economics, equity and sustainable development. Futures 1988, 20, 598-605. [CrossRef]

30. Costanza, R. Valuing natural capital and ecosystem services toward the goals of efficiency, fairness, and sustainability. Ecosyst. Serv. 2020, 43, 101096. [CrossRef]

31. Costanza, R.; D’Arge, R.; De Groot, R.; Farber, S.; Grasso, M.; Hannon, B.; Limburg, K.; Naeem, S.; O’Neill, R.V.; Paruelo, J.; et al The value of the world's ecosystem services and natural capital. Nature 1997, 387, 253-260. [CrossRef]

32. Buchmann-Duck, J.; Beazley, K.F. An urgent call for circular economy advocates to acknowledge its limitations in conserving biodiversity. Sci. Total Environ. 2020, 727, 138602. [CrossRef]

33. Fulton, G.P. Zero discharge of water filtration plant wastewater effluent. Public Works 1973, 104, 86-88. 
34. Chong, M.N.; Jin, B.; Chow, C.W.K.; Saint, C. Recent developments in photocatalytic water treatment technology: A review. Water Res. 2010, 44, 2997-3027. [CrossRef] [PubMed]

35. Spooren, J.; Binnemans, K.; Björkmalm, J.; Breemersch, K.; Dams, Y.; Folens, K.; González-Moya, M.; Horckmans, L.; Komnitsas, K.; Kurylak, W.; et al. Near-zero-waste processing of low-grade, complex primary ores and secondary raw materials in Europe: Technology development trends. Resour. Conserv. Recycl. 2020, 160, 104919. [CrossRef]

36. Binnemans, K.; Jones, P.T.; Blanpain, B.; Van Gerven, T.; Pontikes, Y. Towards zero-waste valorisation of rare-earth-containing industrial process residues: A critical review. J. Clean. Prod. 2015, 99, 17-38. [CrossRef]

37. Geissdoerfer, M.; Savaget, P.; Bocken, N.M.P.; Hultink, E.J. The Circular Economy-A new sustainability paradigm? J. Clean. Prod. 2017, 143, 757-768. [CrossRef]

38. Korhonen, J.; Honkasalo, A.; Seppälä, J. Circular Economy: The Concept and its Limitations. Ecol. Econ. 2018, 143, 37-46. [CrossRef]

39. Suárez-Eiroa, B.; Fernandez, E.; Martínez, G.M.; Soto-Oñate, D. Operational principles of circular economy for sustainable development: Linking theory and practice. J. Clean. Prod. 2019, 214, 952-961. [CrossRef]

40. Bocken, N.M.P.; de Pauw, I.; Bakker, C.A.; van der Grinten, B. Product design and business model strategies for a circular economy. J. Ind. Prod. Eng. 2016, 33, 308-320. [CrossRef]

41. Velenturf, A.P.M.; Archer, S.A.; Gomes, H.I.; Christgen, B.; Brotons, A.J.L.; Purnell, P. Circular economy and the matter of integrated resources. Sci. Total Environ. 2019, 689, 963-969. [CrossRef] [PubMed]

42. Haas, W.; Krausmann, F.; Wiedenhofer, D.; Heinz, M. How Circular is the Global Economy?: An Assessment of Material Flows, Waste Production, and Recycling in the European Union and the World in 2005. J. Ind. Ecol. 2015, 19, 765-777. [CrossRef]

43. Fishman, T.; Graedel, T.E. Impact of the establishment of US offshore wind power on neodymium flows. Nat. Sustain. 2019, 2, 332-338. [CrossRef]

44. Schipper, B.W.; Lin, H.-C.; Meloni, M.A.; Wansleeben, K.; Heijungs, R.; van der Voet, E. Estimating global copper demand until 2100 with regression and stock dynamics. Resour. Conserv. Recycl. 2018, 132, 28-36. [CrossRef]

45. UN. Transforming Our World: The 2030 Agenda for Sustainable Development; UN: New York, NY, USA, 2015.

46. Mackie, C.; Velenturf, A.P.M. Financial security for decommissioing offshore renewable energy installations in UK waters: Trouble on the horizon. Energy Policy 2021, 157, 112479. [CrossRef]

47. Jensen, J.; Skelton, K. Wind turbine blade recycling: Experiences, challenges and possibilities in a circular economy. Renew. Sustain. Energy Rev. 2018, 97, 165-176. [CrossRef]

48. Jensen, J.P. Evaluating the environmental impacts of recycling wind turbines. Wind Energy 2019, 22, 316-326. [CrossRef]

49. Delaney, E.L.; McKinley, J.M.; Megarry, W.; Graham, C.; Leahy, P.G.; Bank, L.C.; Gentry, R. An integrated geospatial approach for repurposing wind turbine blades. Resour. Conserv. Recycl. 2021, 170, 105601. [CrossRef]

50. Kirchherr, J.; Reike, D.; Hekkert, M. Conceptualizing the circular economy: An analysis of 114 definitions. Resour. Conserv. Recycl. 2017, 127, 221-232. [CrossRef]

51. Green Alliance. Less in, More out: Using Resource Efficiency to Cut Carbon and Benefit the Economy; Green Alliance: London, UK, 2018.

52. Circle Economy. Circularity Gap Report 2019; Circle Economy: Amsterdam, The Netherlands, 2019.

53. DEFRA. Environment Bill 2020; Department for Environment, Food \& Rural Affairs: Westminster, UK, 2020.

54. Purnell, P.; Velenturf, A.P.M.; Marshall, R. Chapter 16: New Governance for Circular Economy: Policy, Regulation and Market Contexts for Resource Recovery from Waste. RSC Green Chem. 2020, 2020, 395-422. [CrossRef]

55. Lacy, P.; Rutqvist, J. Waste to Wealth: The Circular Economy Advantage; Pallgrave Macmillan: Basingstoke, UK, $2015 ;$ pp. 1-264.

56. Stahel, W.R. The circular economy. Nature 2016, 531, 435-438. [CrossRef]

57. Liu, X.; Li, Y.; Chen, C.; Zhang, Y.; Chen, D.; Hu, S. Research on high-power pump systems of nongrid connected wind power. In Proceedings of the 2010 World Non-Grid-Connected Wind Power and Energy Conference, WNWEC 2010, Nanjing, China, 5-7 November 2010; pp. 192-197.

58. Pego, A.C. The Portuguese Offshore Energy SWOT Analysis. J. Phys. Conf. Ser. 2019, 1222, 012036. [CrossRef]

59. Lichtenegger, G.; Rentizelas, A.A.; Trivyza, N.; Siegl, S. Offshore and onshore wind turbine blade waste material forecast at a regional level in Europe until 2050. Waste Manag. 2020, 106, 120-131. [CrossRef] [PubMed]

60. Chen, Y.; Cai, G.; Zheng, L.; Zhang, Y.; Qi, X.; Ke, S.; Gao, L.; Bai, R.; Liu, G. Modeling waste generation and end-of-life management of wind power development in Guangdong, China until 2050. Resour. Conserv. Recycl. 2021, 169, 105533. [CrossRef]

61. Chen, S.-H.; Ou, Y.-P. Digital transformation and structural change in Taiwan's national innovation system. In Industrial Development of Taiwan: Past Achievement and Future Challenges Beyond 2020; Routledge: London, UK, 2021; pp. 34-54.

62. Cullen, J.M. Circular Economy: Theoretical Benchmark or Perpetual Motion Machine? J. Ind. Ecol. 2017, 21, 483-486. [CrossRef]

63. Giampietro, M.; Funtowicz, S.O. From elite folk science to the policy legend of the circular economy. Environ. Sci. Policy 2020, 109, 64-72. [CrossRef]

64. OREC; University of Leeds; NCC; OGTC. Sustainable Decommissioning: Wind Turbine Blade Recycling; Offshore Renewable Energy Catapult: Glasgow, UK, 2021.

65. WindEurope; Cefic; EuCIA. Accelerating Wind Turbine Blade Circularity; WindEurope: Brussels, Belgium, 2020.

66. Purnell, P.; Velenturf, A.P.M.; Jensen, P.D.; Cliffe, N.; Jopson, J.S. Developing Technology, Approaches and Business Models for Decommissioning of Low-Carbon Infrastructure; Resource Recovery from Waste: Leeds, UK, 2018. 
67. Van Wijk, A.; Verhoef, L. Our Car as Power Plant; IOS Press: Amsterdam, The Netherlands, 2014; pp. 1-107. [CrossRef]

68. Ji, P.; Zhou, X.X.; Wu, S. Review on sustainable development of island microgrid. In Proceedings of the 2011 International Conference on Advanced Power System Automation and Protection, Beijing, China, 16-20 October 2011; Volume 3, pp. $1806-1813$.

69. Proskuryakova, L.N.; Ermolenko, G.V. The future of Russia's renewable energy sector: Trends, scenarios and policies. Renew. Energy 2019, 143, 1670-1686. [CrossRef]

70. Zambon, I.; Monarca, D.; Cecchini, M.; Bedini, R.; Longo, L.; Romagnoli, M.; Marucci, A. Alternative energy and the development of local rural contexts: An approach to improve the degree of smart cities in the Central-Southern Italy. Contemp. Eng. Sci. 2016, 9 , 1371-1386. [CrossRef]

71. Cascone, S.; Ingrao, C.; Valenti, F.; Porto, S.M. Energy and environmental assessment of plastic granule production from recycled greenhouse covering films in a circular economy perspective. J. Environ. Manag. 2020, 254, 109796. [CrossRef]

72. Díaz-Ramírez, M.; Ferreira, V.J.; García-Armingol, T.; López-Sabirón, A.M.; Ferreira, G. Environmental Assessment of Electrochemical Energy Storage Device Manufacturing to Identify Drivers for Attaining Goals of Sustainable Materials 4.0. Sustainability 2020, 12, 342. [CrossRef]

73. Desing, H.; Widmer, R.; Beloin-Saint-Pierre, D.; Hischier, R.; Wäger, P. Powering a Sustainable and Circular Economy-An Engineering Approach to Estimating Renewable Energy Potentials within Earth System Boundaries. Energies 2019, $12,4723$. [CrossRef]

74. Dong, Q. Study on the development strategy of tourism circular economy based on renewable energy technology. J. Adv. Oxid. Technol. 2018, 21. [CrossRef]

75. Kiviranta, K.; Thomasson, T.; Hirvonen, J.; Tähtinen, M. Connecting circular economy and energy industry: A techno-economic study for the Åland Islands. Appl. Energy 2020, 279, 115883. [CrossRef]

76. Jin, T.; Liao, H.; Taboada, H.; Jimenez, J.; Sun, F. Integration of reliability, service and renewables for sustainable manufacturing initiatives. In Proceedings of the IIE Annual Conference and Expo 2014, Montreal, QC, Canada, 31 May-3 June 2014; pp. 577-586.

77. Kılkış, Ş.; Kilkis, B. Integrated circular economy and education model to address aspects of an energy-water-food nexus in a dairy facility and local contexts. J. Clean. Prod. 2017, 167, 1084-1098. [CrossRef]

78. Carbone, C.; Gracceva, F.; Pierro, N.; Motola, V.; Zong, Y.; You, S.; Pérez-Fortes, M.; Wang, L.; Agostini, A. Potential Deployment of Reversible Solid-Oxide Cell Systems to Valorise Organic Waste, Balance the Power Grid and Produce Renewable Methane: A Case Study in the Southern Italian Peninsula. Front. Energy Res. 2021, 9, 15. [CrossRef]

79. Nadaleti, W.C.; dos Santos, G.B.; Lourenço, V.A. Integration of renewable energies using the surplus capacity of wind farms to generate $\mathrm{H}_{2}$ and electricity in Brazil and in the Rio Grande do Sul state: Energy planning and avoided emissions within a circular economy. Int. J. Hydrogen Energy 2020, 45, 24190-24202. [CrossRef]

80. Rusmanis, D.; O'Shea, R.; Wall, D.M.; Murphy, J.D. Biological hydrogen methanation systems-An overview of design and efficiency. Bioengineered 2019, 10, 604-634. [CrossRef]

81. Eggemann, L.; Escobar, N.; Peters, R.; Burauel, P.; Stolten, D. Life cycle assessment of a small-scale methanol production system: A Power-to-Fuel strategy for biogas plants. J. Clean. Prod. 2020, 271, 122476. [CrossRef]

82. Bazaluk, O.; Havrysh, V.; Nitsenko, V.; Baležentis, T.; Streimikiene, D.; Tarkhanova, E.A. Assessment of Green Methanol Production Potential and Related Economic and Environmental Benefits: The Case of China. Energies 2020, 13, 3113. [CrossRef]

83. Schoden, F.; Siebert, A.; Keskin, A.; Herzig, K.; Straus, M.; Schwenzfeier-Hellkamp, E. Building a Wind Power Plant from Scrap and Raising Public Awareness for Renewable Energy Technology in a Circular Economy. Sustainability 2020, 12, 90. [CrossRef]

84. Huang, Y.L.; Bella, V.D.; Magnano, I.; Harryson, S.; Sciuto, G. Industrial symbiosis-based renewable energy: A sustainable way to draw advantages from Sicily's sun and wind. Procedia Environ. Sci. Eng. Manag. 2019, 6, 149-157.

85. Naqvi, S.R.; Prabhakara, H.M.; Bramer, E.; Dierkes, W.; Akkerman, R.; Brem, G. A critical review on recycling of end-of-life carbon fibre/glass fibre reinforced composites waste using pyrolysis towards a circular economy. Resour. Conserv. Recycl. 2018, 136, 118-129. [CrossRef]

86. Eriksson, O. Energy and Waste Management. Energies 2017, 10, 1072. [CrossRef]

87. Novais, R.M.; Carvalheiras, J.; Seabra, M.; Pullar, R.; Labrincha, J. Effective mechanical reinforcement of inorganic polymers using glass fibre waste. J. Clean. Prod. 2017, 166, 343-349. [CrossRef]

88. Hao, S.; Kuah, A.T.; Rudd, C.D.; Wong, K.H.; Lai, N.Y.G.; Mao, J.; Liu, X. A circular economy approach to green energy: Wind turbine, waste, and material recovery. Sci. Total Environ. 2020, 702, 135054. [CrossRef] [PubMed]

89. Sommer, V.; Stockschläder, J.; Walther, G. Estimation of glass and carbon fiber reinforced plastic waste from end-of-life rotor blades of wind power plants within the European Union. Waste Manag. 2020, 115, 83-94. [CrossRef] [PubMed]

90. Psomopoulos, C.S.; Kalkanis, K.; Kaminaris, S.; Ioannidis, G.C.; Pachos, P. A Review of the Potential for the Recovery of Wind Turbine Blade Waste Materials. Recycling 2019, 4, 7. [CrossRef]

91. Dubey, P.K.; Mahanth, S.K.; Dixit, A.; Changmongkol, S. Recyclable epoxy systems for rotor blades. IOP Conf. Ser. Mater. Sci. Eng. 2021, 942, 012014. [CrossRef]

92. Romani, A.; Mantelli, A.; Suriano, R.; Levi, M.; Turri, S. Additive Re-Manufacturing of Mechanically Recycled End-of-Life Glass Fiber-Reinforced Polymers for Value-Added Circular Design. Materials 2020, 13, 3545. [CrossRef]

93. Joustra, J.; Flipsen, B.; Balkenende, R. Structural reuse of high end composite products: A design case study on wind turbine blades. Resour. Conserv. Recycl. 2021, 167, 105393. [CrossRef] 
94. Cooperman, A.; Eberle, A.; Lantz, E. Wind turbine blade material in the United States: Quantities, costs, and end-of-life options. Resour. Conserv. Recycl. 2021, 168, 105439. [CrossRef]

95. Rentizelas, A.; Trivyza, N.; Oswald, S.; Siegl, S. Reverse supply network design for circular economy pathways of wind turbine blades in Europe. Int. J. Prod. Res. 2021. [CrossRef]

96. Krauklis, A.E.; Karl, C.W.; Gagani, A.I.; Jørgensen, J.K. Composite Material Recycling Technology-State-of-the-Art and Sustainable Development for the 2020s. J. Compos. Sci. 2021, 5, 28. [CrossRef]

97. Lapko, Y.; Trianni, A.; Nuur, C.; Masi, D. In Pursuit of Closed-Loop Supply Chains for Critical Materials: An Exploratory Study in the Green Energy Sector. J. Ind. Ecol. 2019, 23, 182-196. [CrossRef]

98. Nelson, J.J.M.; Schelter, E.J. Sustainable Inorganic Chemistry: Metal Separations for Recycling. Inorg. Chem. 2019, 58, 979-990. [CrossRef] [PubMed]

99. Zhang, J.; Anawati, J.; Yao, Y.; Azimi, G. Aeriometallurgical Extraction of Rare Earth Elements from a NdFeB Magnet Utilizing Supercritical Fluids. ACS Sustain. Chem. Eng. 2018, 6, 16713-16725. [CrossRef]

100. Diehl, O.; Schönfeldt, M.; Brouwer, E.; Dirks, A.; Rachut, K.; Gassmann, J.; Güth, K.; Buckow, A.; Gauß, R.; Stauber, R.; et al. Towards an Alloy Recycling of Nd-Fe-B Permanent Magnets in a Circular Economy. J. Sustain. Met. 2018, 4, 163-175. [CrossRef]

101. Rhodes, C.J. Endangered elements, critical raw materials and conflict minerals. Sci. Prog. 2019, 102, 304-350. [CrossRef]

102. Ranta-Korhonen, T.; Soininen, H. Ash fractions from incineration of municipal waste and solid biofuels as secondary resources for circular economy and recovery of rees. In Proceedings of the 27th European Biomass Conference and Exhibition Proceedings, Lisbon, Portugal, 27-30 May 2019; pp. 163-165.

103. Bonfante, M.C.; Raspini, J.P.; Fernandes, I.B.; Fernandes, S.; Campos, L.M.; Alarcon, O.E. Achieving Sustainable Development Goals in rare earth magnets production: A review on state of the art and SWOT analysis. Renew. Sustain. Energy Rev. 2021, 137, 110616. [CrossRef]

104. Lima, A.T.; Ottosen, L. Recovering rare earth elements from contaminated soils: Critical overview of current remediation technologies. Chemosphere 2021, 265, 129163. [CrossRef]

105. Maani, T.; Mathur, N.; Singh, S.; Rong, C.; Sutherland, J.W. Potential for Nd and Dy Recovery from End-of-Life Products to Meet Future Electric Vehicle Demand in the U.S. Procedia CIRP 2021, 98, 109-114. [CrossRef]

106. Tansel, B. Increasing gaps between materials demand and materials recycling rates: A historical perspective for evolution of consumer products and waste quantities. J. Environ. Manag. 2020, 276, 111196. [CrossRef]

107. Tabelin, C.B.; Dallas, J.; Casanova, S.; Pelech, T.; Bournival, G.; Saydam, S.; Canbulat, I. Towards a low-carbon society: A review of lithium resource availability, challenges and innovations in mining, extraction and recycling, and future perspectives. Miner. Eng. 2021, 163, 106743. [CrossRef]

108. Mulvaney, D.; Richards, R.M.; Bazilian, M.D.; Hensley, E.; Clough, G.; Sridhar, S. Progress towards a circular economy in materials to decarbonize electricity and mobility. Renew. Sustain. Energy Rev. 2021, 137, 110604. [CrossRef]

109. Norgren, A.; Carpenter, A.; Heath, G. Design for Recycling Principles Applicable to Selected Clean Energy Technologies: Crystalline-Silicon Photovoltaic Modules, Electric Vehicle Batteries, and Wind Turbine Blades. J. Sustain. Metall. 2020, 6, 761-774. [CrossRef]

110. Pasquali, F.; Suk, H.; Behdad, S.; Hall, J. Method for design life of energy system components based on Levelized Cost of Energy. J. Clean. Prod. 2020, 268, 121971. [CrossRef]

111. Pasquali, F.M.; Meza, J.; Hall, J.F. Decision-Based Design Method for Computing Marginal Cost of Durability. In Proceedings of the 25th Design for Manufacturing and the Life Cycle Conference (DFMLC), Virtual, Online, 17-19 August 2020.

112. Medici, P.; van den Dobbelsteen, A.; Peck, D. Safety and Health Concerns for the Users of a Playground, Built with Reused Rotor Blades from a Dismantled Wind Turbine. Sustainability 2020, 12, 3626. [CrossRef]

113. Bank, L.; Arias, F.R.; Gentry, T.R.; Al-Haddad, T.; Tasistro-Hart, B.; Chen, J.-F. Structural analysis of FRP parts from waste wind turbine blades for building reuse applications. In Proceedings of the 7th International Conference on Structural Engineering, Mechanics and Computation; Cape Town, South Africa, 2-4 September 2019, pp. 1520-1524.

114. Jensen, J.P.; Prendeville, S.M.; Bocken, N.M.; Peck, D. Creating sustainable value through remanufacturing: Three industry cases. J. Clean. Prod. 2019, 218, 304-314. [CrossRef]

115. Velenturf, A.P.; Jopson, J.S. Making the business case for resource recovery. Sci. Total Environ. 2019, 648, 1031-1041. [CrossRef]

116. Hatzivasilis, G.; Fysarakis, K.; Soultatos, O.; Askoxylakis, I.; Papaefstathiou, I.; Demetriou, G. The Industrial Internet of Things as an enabler for a Circular Economy Hy-LP: A novel IIoT protocol, evaluated on a wind park's SDN/NFV-enabled 5G industrial network. Comput. Commun. 2018, 119, 127-137. [CrossRef]

117. Adibi, N.; Lafhaj, Z.; Yehya, M.; Payet, J. Global Resource Indicator for life cycle impact assessment: Applied in wind turbine case study. J. Clean. Prod. 2017, 165, 1517-1528. [CrossRef]

118. Mathews, J.A.; Huang, C.X. The global green shift in electric power: China in comparative perspective. Asia-Pac. J. Japan Focus 2021, 19, 5589.

119. Lesniewska, F. Renewable energy, waste management and the circular economy in the EU: Solar PV and wind power. In Research Handbook on EU Energy Law and Policy; Edward Elgar Publishing Limited: Cheltenham, UK, 2017; pp. 460-468. [CrossRef]

120. Kopnina, H. Energy Policy in the European Union: Renewable Energy and the Risks of Subversion. In Governance and Security Issues of the European Union; Asser press: The Hague, The Netherlands; Springer Verlag: Berlin/Heidelberg, Germany, 2016; pp. 167-184. 
121. Page, M.J.; McKenzie, J.E.; Bossuyt, P.M.; Boutron, I.; Hoffmann, T.C.; Mulrow, C.D.; Shamseer, L.; Tetzlaff, J.M.; Akl, E.A.; Brennan, S.E.; et al. The PRISMA 2020 statement: An updated guideline for reporting systematic reviews. PLoS Med. 2021, 18, e1003583. [CrossRef]

122. Marsh, A.T.M.; Velenturf, A.P.M.; Bernal, S.A. Circular Economy strategies for concrete: Implementation and integration. Under review.

123. Reike, D.; Vermeulen, W.J.V.; Witjes, S. The circular economy: New or Refurbished as CE 3.0?-Exploring Controversies in the Conceptualization of the Circular Economy through a Focus on History and Resource Value Retention Options. Resour. Conserv. Recycl. 2018, 135, 246-264. [CrossRef]

124. Velenturf, A.P.M. Challenges and Opportunities for Sustainable Offshore Wind Development: Preliminary Findings from a Literature Review and Expert Survey; SRI Working paper series; University of Leeds: Leeds, UK, 2020.

125. Köller, J.; Köppel, J.; Peters, W. Conclusion and perspective. In Offshore Wind Energy: Research on Environmental Impacts; SpringerVerlag: Berlin/Heidelberg, Germany, 2006; pp. 345-352.

126. Amran, Y.A.; Alyousef, R.; Alabduljabbar, H. Renewable and sustainable energy production in Saudi Arabia according to Saudi Vision 2030; Current status and future prospects. J. Clean. Prod. 2020, 247, 119602. [CrossRef]

127. Karakosta, C.; Pappas, C.; Marinakis, V.; Psarras, J. Renewable energy and nuclear power towards sustainable development: Characteristics and prospects. Renew. Sustain. Energy Rev. 2013, 22, 187-197. [CrossRef]

128. Apergis, N.; Payne, J.E.; Menyah, K.; Wolde-Rufael, Y. On the causal dynamics between emissions, nuclear energy, renewable energy, and economic growth. Ecol. Econ. 2010, 69, 2255-2260. [CrossRef]

129. Widger, P.; Haddad, A. Evaluation of SF6 Leakage from Gas Insulated Equipment on Electricity Networks in Great Britain. Energies 2018, 11, 2037. [CrossRef]

130. IEA. World Energy Outlook 2020; IEA: Paris, France, 2020.

131. Morrissey, J.; Heidkamp, C.P. A transitions perspective on coastal sustainability. In Towards Coastal Resilience and Sustainability; Taylor \& Francis Group: London, UK, 2018; pp. 15-32.

132. Busch, J.; Dawson, D.; Roelich, K.; Steinberger, J.; Purnell, P. Enhancing stocks and flows modelling to support sustainable resource management in low carbon infrastructure transitions. In Proceedings of the iEMSs 2012-Managing Resources of a Limited Planet: Proceedings of the 6th Biennial Meeting of the International Environmental Modelling and Software Society, Leipzig, Germany, 1-5 July 2012; pp. 1793-1800.

133. Roelich, K.; Dawson, D.; Purnell, P.; Knoeri, C.; Revell, R.; Busch, J.; Steinberger, J. Assessing the dynamic material criticality of infrastructure transitions: A case of low carbon electricity. Appl. Energy 2014, 123, 378-386. [CrossRef]

134. Soukissian, T.H.; Denaxa, D.; Karathanasi, F.; Prospathopoulos, A.; Sarantakos, K.; Iona, A.; Georgantas, K.; Mavrakos, S. Marine Renewable Energy in the Mediterranean Sea: Status and Perspectives. Energies 2017, 10, 1512. [CrossRef]

135. BBC. US, EU and Japan Challenge China on Rare Earths at WTO; BBC: London, UK, 2012.

136. Borthwick, A.G. Marine Renewable Energy Seascape. Engineering 2016, 2, 69-78. [CrossRef]

137. Herring, R.; Dyer, K.; Martin, F.; Ward, C. The increasing importance of leading edge erosion and a review of existing protection solutions. Renew. Sustain. Energy Rev. 2019, 115, 109382. [CrossRef]

138. Simani, S. Overview of Modelling and Advanced Control Strategies for Wind Turbine Systems. Energies 2015, 8, 13395-13418. [CrossRef]

139. Velenturf, A.P.M. The National Materials Datahub Can Improve Governance for Better Material Use by Industry: An Evidence Briefing from the Resource Recovery from Waste Programme; Resource Recovery from Waste: Leeds, UK, 2019.

140. Ahsan, D.; Pedersen, S. The influence of stakeholder groups in operation and maintenance services of offshore wind farms: Lesson from Denmark. Renew. Energy 2018, 125, 819-828. [CrossRef]

141. Topham, E.; McMillan, D. Sustainable decommissioning of an offshore wind farm. Renew. Energy 2017, 102, 470-480. [CrossRef]

142. Shaker, M.S.; Patton, R.J. A Fault Tolerant Control Approach to Sustainable Offshore Wind Turbines. Adv. Ind. Control 2014, 157-190. [CrossRef]

143. Velenturf, A.P.M.; Purnell, P.; Jensen, P.D. Groundhog Day for Decommissioning? The Case of the Offshore Wind Industry. Invited Presentation at Chartered Institution of Wastes Management London and Southern Counties, Waste Ahoy! Management of Offshore Wastes: London, UK, 2017.

144. Velenturf, A.P.M. Circular Economy Strategies for More Sustainable Wind Energy; Offshore Renewable Energy Catapult: Glasgow, UK, 2020.

145. Velenturf, A.P.M. Towards A Circular Economy Framework for Offshore Wind; Chartered Institution of Wastes Management: Northampton, UK, 2020.

146. Velenturf, A.P.M. Strategies for a Sustainable Circular Economy in Offshore Wind. In Proceedings of the Eolis 2020, Brussels, Belgium, 18-20 November 2021; 2020.

147. Velenturf, A.P.M. Strategies for a Sustainable Circular Economy in Offshore Wind. In Proceedings of the Innovation Offshore: The Role of Offshore Wind in Driving a Green Recovery, Berlin, Germany, 19 November 2020; 2020.

148. Velenturf, A.P.M. Integrating circular economy with energy infrastructure lifecycle management: Knowledge exchange between North Sea oil \& gas and offshore wind. In Proceedings of the Offshore Decommissioning Conference 2020, Aberdeen, UK, 24-25 November 2020. 
149. OREC; Renewable Parts; University of Leeds. Circular Economy for the Offshore wind Industry; Re-energise; Offshore Renewable Energy Catapult: Glasgow, UK, 2020.

150. WindEurope. Offshore Wind Infrastructure in a Sustainable Circular Economy. In Business News Live; Wind Energy Hamburg: Hamburg, Germany, 2020.

151. Velenturf, A.P.M. Circular Economy Business Opportunities in Offshore Wind: Workshop Proceedings; University of Leeds: Leeds, UK, 2021.

152. Parrique, T.; Barth, J.; Briens, F.; Kerschner, C.; Kraus-Polk, A.; Kuokkanen, A.; Spangenberg, J.H. Decoupling Debunked: Evidence and Arguments against Green Growth As a Sole Strategy for Sustainability; European Environmental Bureau: Brussel, Belgium, 2019.

153. Wiedmann, T.; Schandl, H.; Lenzen, M.; Moran, D.; Suh, S.; West, J.; Kanemoto, K. The material footprint of nations. Proc. Natl. Acad. Sci. USA 2015, 112, 6271-6276. [CrossRef]

154. Wiedmann, T.; Lenzen, M.; Keyßer, L.T.; Steinberger, J.K. Scientists' warning on affluence. Nat. Commun. 2020, 11, 3107. [CrossRef] [PubMed]

155. Bakker, C.; Wang, F.; Huisman, J.; Hollander, M.D. Products that go round: Exploring product life extension through design. J. Clean. Prod. 2014, 69, 10-16. [CrossRef]

156. Andrews, D. The circular economy, design thinking and education for sustainability. Local Econ. 2015, 30, 305-315. [CrossRef]

157. Yang, J.; Zhang, L.; Chang, Y.; Hao, Y.; Liu, G.; Yan, Q.; Zhao, Y. Understanding the material efficiency of the wind power sector in China: A spatial-temporal assessment. Resour. Conserv. Recycl. 2020, 155, 104668. [CrossRef]

158. DEFRA. Guidance on Applying the Waste Hierarchy 2011; Department for Environment, Food \& Rural Affairs: Westminster, UK, 2011.

159. Francis, C.G. The chemical industry from an industrial ecology perspective. In Perspectives on Industrial Ecology; Bourg, D., Erkman, S., Eds.; Greenleaf Publishing Limited: Sheffield, UK, 2003; pp. 120-135.

160. Laybourn, P.; Morrissey, M. National Industrial Symbiosis Programme: The Pathway to a Low Carbon Sustainable Economy; International Synergies Ltd.: Kings Norton, UK, 2009.

161. Jensen, P.D.; Basson, L.; Hellawell, E.; Bailey, M.R.; Leach, M. Quantifying 'geographic proximity': Experiences from the United Kingdom's National Industrial Symbiosis Programme. Resour. Conserv. Recycl. 2011, 55, 703-712. [CrossRef]

162. Nguyen, H.T.; Pearce, J.M. Renewable Powered Desalination in the Coastal Mekong Delta. In Proceedings of the ASME 20104 th International Conference on Energy Sustainability, Phoenix, AZ, USA, 17-22 May 2010; pp. 935-946.

163. Kikuchi, Y.; Kanematsu, Y.; Okubo, T. A computer-aided scenario analysis of national and regional energy systems based on feasible technology options. Computer Aided Chem. Eng. 2016, 38, 1959-1964. [CrossRef]

164. Sedlar, D.K.; Vulin, D.; Krajačić, G.; Jukić, L. Offshore gas production infrastructure reutilisation for blue energy production. Renew. Sustain. Energy Rev. 2019, 108, 159-174. [CrossRef]

165. Den Hollander, M.C.; Bakker, C.A.; Hultink, E.J. Product Design in a Circular Economy: Development of a Typology of Key Concepts and Terms. J. Ind. Ecol. 2017, 21, 517-525. [CrossRef]

166. EU. Directive 2008/98/EC of the European Parliament and of the Council of 19 November 2008 on Waste and Repealing Certain Directives (Text with EEA Relevance); EU: Brussels, Belgium, 2008.

167. Gentry, T.R.; Al-Haddad, T.; Bank, L.C.; Arias, F.R.; Nagle, A.; Leahy, P. Structural Analysis of a Roof Extracted from a Wind Turbine Blade. J. Arch. Eng. 2020, 26, 04020040. [CrossRef]

168. Bank, L.; Arias, F.R.; Yazdanbakhsh, A.; Gentry, T.R.; Al-Haddad, T.; Chen, J.-F.; Morrow, R. Concepts for Reusing Composite Materials from Decommissioned Wind Turbine Blades in Affordable Housing. Recycling 2018, 3, 3. [CrossRef]

169. Zaaijer, M.B. Integrated offshore wind farm planning and design. In Wind Energy Systems: Optimising Design and Construction for Safe and Reliable Operation; Woodhead Publishing Limited: Cambridge, UK, 2010; pp. 519-545.

170. Iliopoulos, A.N.; Weijtjens, W.; Van Hemelrijck, D.; Devriendt, C. Remaining useful life assessment of offshore wind turbines: Validation of virtual sensing on long term measurements. In Proceedings of the 8th European Workshop on Structural Health Monitoring, EWSHM 2016, Bilbao, Spain, 5-8 July 2016; pp. 2312-2319.

171. Sun, H.; Yang, H.; Gao, X. Study on offshore wind farm layout optimization based on decommissioning strategy. Energy Procedia 2017, 143, 566-571. [CrossRef]

172. Oudman, B.L. Green decommissioning: Re-use of north sea offshore assets in a sustainable energy future. In Proceedings of the Offshore Mediterranean Conference and Exhibition 2017, OMC 2017, Ravenna, Italy, 29-31 March 2017.

173. Barros, J.C.; Fernandes, G.C.; Silva, M.M.; Da Silva, R.P.; Santos, B. Fixed platforms at ageing oil fields—Feasibility study for reuse to wind farms. In Proceedings of the Annual Offshore Technology Conference, Houston, TX, USA, 1-4 May 2017 ; pp. 4564-4581.

174. Klabučar, B.; Sedlar, D.K.; Smajla, I. Analysis of blue energy production using natural gas infrastructure: Case study for the Northern Adriatic. Renew. Energy 2020, 156, 677-688. [CrossRef]

175. Schaffel, S.B.; Westin, F.F.; Hernandez, O.M.; La Rovere, E.L. Replacing Fossil Fuels by Wind Power in Energy Supply to Offshore Oil\&Gas Exploration and Production Activities-Possibilities for Brazil. In Proceedings of the Offshore Technology Conference Brasil 2019, OTCB 2019, Rio de Janeiro, Brazil, 29-31 October 2019.

176. Boman, K. Reduce, reuse, recycle. Offshore Eng. 2017, 42, 34-35.

177. Topham, E.; Gonzalez, E.; McMillan, D.; João, E. Challenges of decommissioning offshore wind farms: Overview of the European experience. J. Phys. Conf. Ser. 2019, 1222, 012035. [CrossRef] 
178. Luengo, M.M.; Kolios, A. Failure Mode Identification and End of Life Scenarios of Offshore Wind Turbines: A Review. Energies 2015, 8, 8339-8354. [CrossRef]

179. Bezbradica, M.; Kerkvliet, H.; Borbolla, I.M.; Lehtimaki, P. Introducing multi-criteria decision analysis for wind farm repowering: A case study on Gotland. In Proceedings of the 1st International Conference on Multidisciplinary Engineering Design Optimization, MEDO 2016, Belgrade, Serbia, 14-16 September 2016.

180. Noppe, N.; Hübler, C.; Devriendt, C.; Weijtjens, W. Validated extrapolation of measured damage within an offshore wind farm using instrumented fleet leaders. J. Phys. Conf. Ser. 2020, 1618, 022005. [CrossRef]

181. Henkel, M.; Häfele, J.; Weijtjens, W.; Devriendt, C.; Gebhardt, C.G.; Rolfes, R. Strain estimation for offshore wind turbines with jacket substructures using dual-band modal expansion. Mar. Struct. 2020, 71, 102731. [CrossRef]

182. Bouty, C.; Schafhirt, S.; Ziegler, L.; Muskulus, M. Lifetime extension for large offshore wind farms: Is it enough to reassess fatigue for selected design positions? Energy Procedia 2017, 137, 523-530. [CrossRef]

183. Stutzmann, J.; Ziegler, L.; Muskulus, M. Fatigue Crack Detection for Lifetime Extension of Monopile-based Offshore Wind Turbines. Energy Procedia 2017, 137, 143-151. [CrossRef]

184. Ziegler, L.; Cosack, N.; Kolios, A.; Muskulus, M. Structural monitoring for lifetime extension of offshore wind monopiles: Verification of strain-based load extrapolation algorithm. Mar. Struct. 2019, 66, 154-163. [CrossRef]

185. Ziegler, L.; Muskulus, M. Comparing a Fracture Mechanics Model to the SN-Curve Approach for Jacket-Supported Offshore Wind Turbines: Challenges and Opportunities for Lifetime Prediction. In Proceedings of the International Conference on Offshore Mechanics and Arctic Engineering-OMAE, Busan, Korea, 19-24 June 2016.

186. Ziegler, L.; Muskulus, M. Fatigue reassessment for lifetime extension of offshore wind monopile substructures. J. Phys. Conf. Ser. 2016, 753, 92010. [CrossRef]

187. Ziegler, L.; Smolka, U.; Cosack, N.; Muskulus, M. Brief communication: Structural monitoring for lifetime extension of offshore wind monopiles: Can strain measurements at one level tell us everything? Wind Energy Sci. 2017, 2, 469-476. [CrossRef]

188. Hübler, C.; Weijtjens, W.; Rolfes, R.; Devriendt, C. Reliability analysis of fatigue damage extrapolations of wind turbines using offshore strain measurements. J. Phys. Conf. Ser. 2018, 1037, 032035. [CrossRef]

189. Rahim, A.; Sparrevik, P.; Mirdamadi, A. Structural Health Monitoring for Offshore Wind Turbine Towers and Foundations. In Proceedings of the Annual Offshore Technology Conference, Houston, TX, USA, 30 April-3 May 2018; pp. 3181-3198.

190. Fallais, D.; Voormeeren, S.; Lourens, E.-M. Vibration-based Identification of Hydrodynamic Loads and System Parameters for Offshore Wind Turbine Support Structures. Energy Procedia 2016, 94, 191-198. [CrossRef]

191. Beganovic, N.; Soeffker, D. Structural health management utilization for lifetime prognosis and advanced control strategy deployment of wind turbines: An overview and outlook concerning actual methods, tools, and obtained results. Renew. Sustain. Energy Rev. 2016, 64, 68-83. [CrossRef]

192. Energy Procedia. In Proceedings of the 14th Deep Sea Offshore Wind R and D Conference, EERA DeepWind 2017, Trondheim, Norway, 18-20 January 2017; Volume 137, p. 133177.

193. Petrovska, E.; Le Dreff, J.-B.; Oterkus, S.; Thies, P.; McCarthy, E. Application of Structural Monitoring Data for Fatigue Life Predictions of Monopile-Supported Offshore Wind Turbines. In Proceedings of the International Conference on Offshore Mechanics and Arctic Engineering-OMAE, Virtual, Online, 3-7 August 2020.

194. Augustyn, D.; Tygesen, U.T.; Ulriksen, M.D.; Sørensen, J.D. Data-driven design and operation of offshore wind structures. In Proceedings of the International Offshore and Polar Engineering Conference, Honolulu, HI, USA, 16-21 June 2019; pp. 491-498.

195. He, W.; Grant, R.J.; Baden, V.; Suntharalingam, J. Innovative alternatives for repowering offshore wind farms. J. Phys. Conf. Ser. 2020, 1618, 042037. [CrossRef]

196. Natarajan, A.; Pedersen, T.F. Remaining Life Assessment of Offshore Wind Turbines Subject to Curtailment. In Proceedings of the International Offshore and Polar Engineering Conference, Sapporo, Japan, 10-15 June 2018; pp. 527-532.

197. Mehmanparast, A.; Vidament, A. An accelerated corrosion-fatigue testing methodology for offshore wind applications. Eng. Struct. 2021, 240, 112414. [CrossRef]

198. Anandavijayan, S.; Mehmanparast, A.; Braithwaite, J.; Brennan, F.; Chahardehi, A. Material pre-straining effects on fatigue behaviour of S355 structural steel. J. Constr. Steel Res. 2021, 183, 106707. [CrossRef]

199. Hou, P.; Enevoldsen, P.; Hu, W.; Chen, C.; Chen, Z. Offshore wind farm repowering optimization. Appl. Energy 2017, 208, 834-844. [CrossRef]

200. Sun, H.; Gao, X.; Yang, H. Investigation into offshore wind farm repowering optimization in Hong Kong. Int. J. Low-Carbon Technol. 2019, 14, 302-311. [CrossRef]

201. Safaei, F.; Tazi, N.; Chatelet, E.; Bouzidi, Y. Optimal Topology and Repowering Time for Offshore Wind Turbines. In Proceedings of the 2019 6th International Conference on Control, Decision and Information Technologies (CoDIT), Paris, France, 23-26 April 2019; pp. 1344-1349.

202. Arvesen, A.; Hertwich, E. Environmental implications of large-scale adoption of wind power: A scenario-based life cycle assessment. Environ. Res. Lett. 2011, 6. [CrossRef]

203. Himpler, S.; Madlener, R. Optimal timing of wind farm repowering: A two-factor real options analysis. J. Energy Mark. 2014, 7, 3-34. [CrossRef]

204. Jadali, A.M.; Ioannou, A.; Salonitis, K.; Kolios, A. Decommissioning vs. repowering of offshore wind farms-a techno-economic assessment. Int. J. Adv. Manuf. Technol. 2021, 112, 2519-2532. [CrossRef] 
205. Zuo, T.; Zhang, Y.; Meng, K.; Tong, Z.; Dong, Z.Y.; Fu, Y. Collector System Topology Design for Offshore Wind Farm's Repowering and Expansion. IEEE Trans. Sustain. Energy 2021, 12, 847-859. [CrossRef]

206. Pakenham, B.; Ermakova, A.; Mehmanparast, A. A Review of Life Extension Strategies for Offshore Wind Farms Using TechnoEconomic Assessments. Energies 2021, 14, 1936. [CrossRef]

207. Grau, L.; Jung, C.; Schindler, D. Sounding out the repowering potential of wind energy-A scenario-based assessment from Germany. J. Clean. Prod. 2021, 293, 126094. [CrossRef]

208. De Bona, J.C.; Ferreira, J.C.E.; Duran, J.F.O. Analysis of scenarios for repowering wind farms in Brazil. Renew. Sustain. Energy Rev. 2021, 135, 110197. [CrossRef]

209. Boopathi, K.; Ramaswamy, S.; Kirubakaran, V.; Uma, K.; Saravanan, G.; Thyagaraj, S.; Balaraman, K. Economic investigation of repowering of the existing wind farms with hybrid wind and solar power plants: A case study. Int. J. Energy Environ. Eng. 2021. [CrossRef]

210. Kitzing, L.; Jensen, M.K.; Telsnig, T.; Lantz, E. Multifaceted drivers for onshore wind energy repowering and their implications for energy transition. Nat. Energy 2020, 5, 1012-1021. [CrossRef]

211. Fuchs, C.; Kasten, J.; Vent, M. Current State and Future Prospective of Repowering Wind Turbines: An Economic Analysis. Energies 2020, 13, 3048. [CrossRef]

212. Piel, J.; Stetter, C.; Heumann, M.; Westbomke, M.; Breitner, M.H. Lifetime Extension, Repowering or Decommissioning? Decision Support for Operators of Ageing Wind Turbines. J. Phys. Conf. Ser. 2019, 1222, 012033. [CrossRef]

213. Windemer, R. Considering time in land use planning: An assessment of end-of-life decision making for commercially managed onshore wind schemes. Land Use Policy 2019, 87, 104024. [CrossRef]

214. Vicente-Ramirez, J.; Garcia-Vasquez, E.; Iracheta-Cortez, R.; Dorrego-Portela, J.R. Economic feasibility study for the repowering of La V enta I and La V enta II wind farms in Mexico. In Proceedings of the 2019 IEEE 39th Central America and Panama Convention, CONCAPAN 2019, Guatemala City, Guatemala, 20-22 November 2019.

215. Madlener, R.; Glensk, B.; Gläsel, L. Optimal Timing of Onshore Wind Repowering in Germany under Policy Regime Changes: A Real Options Analysis. Energies 2019, 12, 4703. [CrossRef]

216. Windemer, R.; Cowell, R. Are the impacts of wind energy reversible? Critically reviewing the research literature, the governance challenges and presenting an agenda for social science. Energy Res. Soc. Sci. 2021, 79, 102162. [CrossRef]

217. Priyono, A.; Ijomah, W.; Bititci, U. Disassembly for remanufacturing: A systematic literature review, new model development and future research needs. J. Ind. Eng. Manag. 2016, 9, 899-932. [CrossRef]

218. Lieder, M.; Rashid, A. Towards circular economy implementation: A comprehensive review in context of manufacturing industry. J. Clean. Prod. 2016, 115, 36-51. [CrossRef]

219. EU (European Union); IRP (International Resource Panel); G7 ARE (G7 Alliance on Resource Efficiency). Workshop Report: Promoting Remanufacturing, Refurbishment, Repair, and Direct Reuse; European Union: Brussels, Belgium, 2017.

220. Matsumoto, M.; Ijomah, W. Remanufacturing. In Handbook of Sustainable Engineering; Kauffman, J., Lee, K.-M., Eds.; Springer: Dordrecht, The Netherlands, 2013.

221. Ness, D. Sustainable urban infrastructure in China: Towards a Factor 10 improvement in resource productivity through integrated infrastructure systems. Int. J. Sustain. Dev. World Ecol. 2008, 15, 288-301. [CrossRef]

222. Priyono, A. Understanding the benefits of product-service system for involved parties in remanufacturing. J. Ind. Eng. Manag. 2017, 10, 323-351. [CrossRef]

223. Gertmar, L.; Reza, M.; Parres, A.; Tenca, P.; Svechkarenko, D.; Peretti, L.; Islam, J. Wind power-from shafts to transmission systems on land-looking forward and back. In Proceedings of the European Wind Energy Conference and Exhibition 2012, EWEC 2012, Copenhagen, Denmark, 16-19 April 2012; pp. 1947-1951.

224. Dorn, J.; Huang, H.; Retzmann, D. Novel voltage-Sourced Converters for HVDC and FACTS applications. In Proceedings of the CIGRE Symposium Osaka 2007: System Development and Asset Management under Restructuring, Osaka, Japan, 1-4 November 2007.

225. Junior, V.L.J.; Zhou, J.; Roshanmanesh, S.; Hayati, F.; Hajiabady, S.; Li, X.Y.; Dong, H.; Papaelias, M. Evaluation of damage mechanics of industrial wind turbine gearboxes. Insight Non-Destr. Test. Cond. Monit. 2017, 59, 410-414. [CrossRef]

226. Junior, V.L.J.; Zhou, J.; Roshanmanesh, S.; Hayati, F.; Hajiabady, S.; Li, X.Y.; Dong, H.; Papaelias, M. Evaluation of damage mechanics of industrial wind turbine gearboxes. In Proceedings of the WCCM 2017-1st World Congress on Condition Monitoring 2017, London, UK, 13-16 June 2017.

227. Dahane, M.; Sahnoun, M.; Bettayeb, B.; Baudry, D.; Boudhar, H. Impact of spare parts remanufacturing on the operation and maintenance performance of offshore wind turbines: A multi-agent approach. J. Intell. Manuf. 2017, 28, 1531-1549. [CrossRef]

228. Parlier, G.; Liberatore, F.; Demange, M. (Eds.) Operations Research and Enterprise Systems. In Proceedings of the 6th International Conference on Operations Research and Enterprise Systems (ICORES 2017), Porto, Portugal, $23-25$ February 2018 ; Volume 884.

229. Hamzah, S.K.; Lacey, G.; Pillai, G. Optimization Modeling for Offshore Wind Farms. In Proceedings of the 2020 55th International Universities Power Engineering Conference (UPEC), Turin, Italy, 1-4 September 2020.

230. Conlon, T.; Waite, M.; Modi, V. Assessing new transmission and energy storage in achieving increasing renewable generation targets in a regional grid. Appl. Energy 2019, 250, 1085-1098. [CrossRef]

231. Pierri, E.; Binder, O.; Hemdan, N.; Kurrat, M. Challenges and opportunities for a European HVDC grid. Renew. Sustain. Energy Rev. 2017, 70, 427-456. [CrossRef] 
232. Hagelüken, C.; Lee-Shin, J.U.; Carpentier, A.; Heron, C. The EU Circular Economy and Its Relevance to Metal Recycling. Recycling 2016, 1, 242-253. [CrossRef]

233. Nordby, A.S. Barriers and opportunities to reuse of building materials in the Norwegian construction sector. IOP Conf. Ser. Earth Environ. Sci. 2019, 225, 012061. [CrossRef]

234. Kopnina, H. Towards Ecological Management: Identifying Barriers and Opportunities in Transition from Linear to Circular Economy. Philos. Manag. 2021, 20, 5-19. [CrossRef]

235. Barbaritano, M.; Bravi, L.; Savelli, E. Sustainability and Quality Management in the Italian Luxury Furniture Sector: A Circular Economy Perspective. Sustainability 2019, 11, 3089. [CrossRef]

236. Milios, L.; Matsumoto, M. Consumer Perception of Remanufactured Automotive Parts and Policy Implications for Transitioning to a Circular Economy in Sweden. Sustainability 2019, 11, 6264. [CrossRef]

237. Thies, P.R.; Johanning, L.; Bashir, I.; Tuk, T.; Tuk, M.; Marta, M.; Müller-Schütze, S. Accelerated reliability testing of articulated cable bend restrictor for offshore wind applications. Int. J. Mar. Energy 2016, 16, 65-82. [CrossRef]

238. Jordaens, P.J.; Milis, S.; Van Riet, N.; Devriendt, C. The use of a large climate chamber for extreme temperature testing \& turbine component validation. In Proceedings of the European Wind Energy Conference and Exhibition, EWEC 2013, Vienna, Austra, 4-7 February 2013; pp. 181-186.

239. Rajesh, J. The cape wind project. Oil Gas J. 2011, 109, 26-27.

240. Woebbeking, M.; Argyriadis, K. New guidelines for the certification of offshore wind turbines. In Proceedings of the International Offshore and Polar Engineering Conference, Anchorage, AK, USA, 30 June-5 July 2013; pp. 114-118.

241. Van Der Valk, P.L.C.; Voormeeren, S.N.; De Valk, P.C.; Rixen, D.J. Dynamic Models for Load Calculation Procedures of Offshore Wind Turbine Support Structures: Overview, Assessment, and Outlook. J. Comput. Nonlinear Dyn. 2015, 10, 041013. [CrossRef]

242. Kerin, M.; Pham, D.T. A review of emerging industry 4.0 technologies in remanufacturing. J. Clean. Prod. 2019, 237, 237. [CrossRef]

243. Priyono, A.; Ijomah, W.; Bititci, U.S. Strategic operations framework for disassembly in remanufacturing. J. Remanuf. 2015, 5, 11. [CrossRef]

244. Sitcharangsie, S.; Ijomah, W.; Wong, T. Decision makings in key remanufacturing activities to optimise remanufacturing outcomes: A review. J. Clean. Prod. 2019, 232, 1465-1481. [CrossRef]

245. Sommerville, R.; Shaw-Stewart, J.; Goodship, V.; Rowson, N.; Kendrick, E. A review of physical processes used in the safe recycling of lithium ion batteries. Sustain. Mater. Technol. 2020, 25, e00197. [CrossRef]

246. Jia, J.; Dou, S.; Yang, S.; Wu, Y.; Cao, F.; Li, B.; Cui, H. Study on the application framework of BIM in the life cycle management of offshore wind farms. In Proceedings of the International Offshore and Polar Engineering Conference, Honolulu, HI, USA, 16-21 June 2019; pp. 513-520.

247. Mignacca, B.; Locatelli, G.; Velenturf, A. Modularisation as enabler of circular economy in energy infrastructure. Energy Policy 2020, 139, 111371. [CrossRef]

248. Hata, T.; Kat, S.; Kimura, F. Design of product modularity for life cycle management. In Proceedings of the Second International Symposium on Environmentally Conscious Design and Inverse Manufacturing, Tokyo, Japan, 11-15 December 2001; pp. 93-96.

249. Kimura, F.; Kato, S.; Hata, T.; Masuda, T. Product Modularization for Parts Reuse in Inverse Manufacturing. CIRP Ann. 2001, 50, 89-92. [CrossRef]

250. Allwood, J.; Ashby, M.F.; Gutowski, T.G.; Worrell, E. Material efficiency: A white paper. Resour. Conserv. Recycl. 2011, 55, 362-381. [CrossRef]

251. Ding, L.; Li, Y.W. Multilevel CSC System Based on Series-Parallel Connected Three-Phase Modules With Optimized Carrier-Shift SPWM. IEEE Trans. Power Electron. 2021, 36, 3957-3966. [CrossRef]

252. Xing, J.; Wang, T.; Wang, D. Design and Research of Modular Multiphase Permanent Magnet Direct Drive Generator. In Proceedings of the 2019 22nd International Conference on Electrical Machines and Systems (ICEMS), Harbin, China, 11-14 August 2019.

253. Petersen, K.R.; Madsen, E.S.; Bilberg, A. First Lean, then modularization: Improving the maintenance of offshore wind turbines. Int. J. Energy Sect. Manag. 2016, 10, 221-244. [CrossRef]

254. Soloot, A.H.; Høidalen, H.K.; Gustavsen, B. Influence of the winding design of wind turbine transformers for resonant overvoltage vulnerability. IEEE Trans. Dielectr. Electr. Insul. 2015, 22, 1250-1257. [CrossRef]

255. Yeter, B.; Garbatov, Y.; Soares, C. Modular jacket offshore wind turbine support structure for the Northern Portuguese coastal zone. In Proceedings of the Progress in Renewable Energies Offshore-Proceedings of 2nd International Conference on Renewable Energies Offshore, RENEW 2016, Lisbon, Portugal, 24-26 October 2016; pp. 655-666. [CrossRef]

256. Sun, J.; Sanz, S.; Ramalingam, R.; Neumann, H. Prototype modular cryostat utilized for $10 \mathrm{MW}$ offshore superconducting wind turbine. Refrigeration Science and Technology. In Proceedings of the 14th IIR International Conference, Dresden, Germany, 15-19 May 2017; pp. 120-125.

257. Adam, F.; Walia, D.; Hartmann, H.; Schünemann, P.; Großmann, J. A Novel Modular TLP-Design for Offshore Wind Turbines Using Ultra High Performance Concrete. Lect. Notes Civ. Eng. 2019, 37, 257-268. [CrossRef]

258. Arlabán, T.; Comech, M.P.; Villén, M.T.; Cova, M.A.; García-Gracia, M. Effects of the modularity in PMSM synchronous machine behaviour. In Proceedings of the CIGRE Session 45-45th International Conference on Large High Voltage Electric Systems 2014, Paris, France, 24-29 August 2014. 
259. Welstead, J.; Hirst, R.; Keogh, D.; Robb, G.; Bainsfair, R. Research and Guidance on Restoration and Decommissioning of Onshore Wind Farms; Scottish Natural Heritage Commissioned Report No. 591; Scottish Natural Heritage: Inverness, Scotland, 2013.

260. Smith, G.; Lamont, G. Decommissioning of Offshore Wind Installations-What we can learn. In Proceedings of the Offshore Wind Energy 2017, London, UK, 6-8 June 2017.

261. Xu, W.; Liu, Y.; Wu, W.; Dong, Y.; Lu, W.; Liu, Y.; Zhao, B.; Li, H.; Yang, R. Proliferation of offshore wind farms in the North Sea and surrounding waters revealed by satellite image time series. Renew. Sustain. Energy Rev. 2020, 133, 110167. [CrossRef]

262. Kruse, M. Energy Transition: Where is the Long-Term Thinking on Offshore Wind Energy? Wirtschaftsdienst 2020, 100, 695-700. [CrossRef]

263. Gudmestad, O.T.; Grønli, J.; Straume, H. Marine operations for installation and intervention of offshore wind turbines. In Proceedings of the RINA, Royal Institution of Naval Architects-Marine Renewable and Offshore Wind Energy-Papers, London, UK, 21-23 April 2010; pp. 175-183.

264. Kaiser, M.J.; Snyder, B.F. Offshore Wind Energy Cost Modeling. Green Energy Technol. 2012, 85. [CrossRef]

265. Kaiser, M.J.; Snyder, B. Modeling the decommissioning cost of offshore wind development on the U.S. Outer Continental Shelf. Mar. Policy 2012, 36, 153-164. [CrossRef]

266. Kaiser, M.J.; Snyder, B.F. Modeling offshore wind installation costs on the U.S. Outer Continental Shelf. Renew. Energy 2013, 50, 676-691. [CrossRef]

267. Shafiee, M.; Brennan, F.; Espinosa, I.A. Towards whole life-cycle costing of large-scale offshore wind farms. In Proceedings of the European Wind Energy Association Annual Conference and Exhibition 2015, EWEA 2015-Scientific Proceedings, Paris, France, 17-20 November 2015; pp. 140-144.

268. Shafiee, M.; Brennan, F.; Espinosa, I. Development of a whole life cost model for offshore wind farms. In Proceedings of the Safety and Reliability of Complex Engineered Systems-Proceedings of the 25th European Safety and Reliability Conference, ESREL 2015, Zurich, Swaziland, 7-10 September 2015; pp. 1019-1027.

269. McAuliffe, F.D.; Desmond, C.; Chester, R.; Flannery, B.; Judge, F.; Lynch, K.; Murphy, J. A tool to simulate decommissioning offshore wind farms. J. Phys. Conf. Ser. 2019, 1356, 012021. [CrossRef]

270. Castro-Santos, L. Decision variables for floating offshore wind farms based on life-cycle cost: The case study of Galicia (North-West of Spain). Ocean Eng. 2016, 127, 114-123. [CrossRef]

271. Irawan, C.A.; Wall, G.; Jones, D.F. An optimisation model for scheduling the decommissioning of an offshore wind farm. OR Spectr. 2019, 41, 513-548. [CrossRef]

272. Hou, P.; Hu, W.; Soltani, M.; Zhang, B.; Chen, Z. Optimization of decommission strategy for offshore wind farms. In Proceedings of the 2016 IEEE Power and Energy Society General Meeting (PESGM), Boston, MA, USA, 17-21 July 2016.

273. Adedipe, T.; Shafiee, M. An economic assessment framework for decommissioning of offshore wind farms using a cost breakdown structure. Int. J. Life Cycle Assess. 2021, 26, 344-370. [CrossRef]

274. Gjødvad, J.F.; Ibsen, M.D. ODIN-WIND: An Overview of the Decommissioning Process for Offshore Wind Turbines. In MAREWINT: New Materials and Reliability in Offshore Wind Turbine Technology; Springer International Publishing: Cham, Switzerland, 2016; pp. 403-419.

275. Hinzmann, N.; Stein, P.; Gattermann, J. Decommissioning of Offshore Monopiles, Occuring Problems and Alternative Solutions. In Proceedings of the International Conference on Offshore Mechanics and Arctic Engineering-OMAE, Madrid, Spain, 17-22 June 2018.

276. Scott, T. Dynamic ports for a dynamic market: Visiting the Dutch offshore ports. Marit. Holl. 2016, 65, 64-68.

277. Kerkvliet, H.; Polatidis, H. Offshore wind farms' decommissioning: A semi quantitative Multi-Criteria Decision Aid framework. Sustain. Energy Technol. Assess. 2016, 18, 69-79. [CrossRef]

278. Maheri, A.; Jalili, S. A Decision Support System for Decommissioning of Offshore Windfarms: The Data Platform. In Proceedings of the 2021 6th International Symposium on Environment-Friendly Energies and Applications (EFEA), Sofia, Bulgaria, 24-26 March 2021.

279. McGugan, M.; McKirdy, S. Structural health monitoring tools for late \& end of life management of offshore wind turbines. In Proceedings of the 8th European Workshop on Structural Health Monitoring, EWSHM 2016, Bilbao, Spain, 8 July 2016; pp. 2420-2429.

280. Galinos, C.; Dimitrov, N.K.; Larsen, T.; Natarajan, A.; Hansen, K.S. Mapping Wind Farm Loads and Power Production-A Case Study on Horns Rev 1. J. Phys. Conf. Ser. 2016, 753, 032010. [CrossRef]

281. Jensen, B.B. Specifying corrosion protection for the offshore wind turbine industry. NACE Int. Corros. Conf. Ser. 2017, 3, 1936-1946.

282. Cabboi, A.; Segeren, M.; Hendrikse, H.; Metrikine, A. Vibration-assisted installation and decommissioning of a slip-joint. Eng. Struct. 2020, 209, 109949. [CrossRef]

283. Sanders, N.; Haynes, T.; Goriup, P.D. Marine Protected Areas and Offshore Wind Farms. In Management of Marine Protected Areas: A Network Perspective; Wiley-Blackwell: Chichester, UK, 2017; pp. 263-280.

284. Carlos, R.G. Very shallow water noise impact of offshore windfarms. In Parameters to be considered. In Proceedings of the 15th International Congress on Sound and Vibration 2008, ICSV 2008, Daejeon, Korea, 6-10 July 2008; pp. $1074-1081$.

285. Hall, R.; João, E.; Knapp, C.W. Environmental impacts of decommissioning: Onshore versus offshore wind farms. Environ. Impact Assess. Rev. 2020, 83, 106404. [CrossRef] 
286. C, O.M.H.; Shadman, M.; Amiri, M.M.; Silva, C.; Estefen, S.F.; La Rovere, E. Environmental impacts of offshore wind installation, operation and maintenance, and decommissioning activities: A case study of Brazil. Renew. Sustain. Energy Rev. 2021, $144,110994$. [CrossRef]

287. Januário, C.; Semino, S.; Bell, M. Offshore Windfarm Decommissioning: A proposal for guidelines to be included in the European Maritime Policy. In Proceedings of the European Wind Energy Conference and Exhibition 2007, EWEC 2007, Milan, Italy, 7-10 May 2007; pp. 362-371.

288. Feld, T. New risks and rewards in offshore wind energy. In Proceedings of the NGCWP 2007-Proceedings of 2007 Non-GridConnected Wind Power Systems_-Wind Power Shanghai 2007-Symposium on Non-Grid-Connected Wind Power 2007, San Diego, CA, USA, 10-15 June 2007; pp. 441-448.

289. González, M.O.A.; Santiso, A.M.; de Melo, D.C.; de Vasconcelos, R.M. Regulation for offshore wind power development in Brazil. Energy Policy 2020, 145, 111756. [CrossRef]

290. Jørgensen, D. OSPAR's exclusion of rigs-to-reefs in the North Sea. Ocean Coast. Manag. 2012, 58, 57-61. [CrossRef]

291. Bull, A.S.; Love, M.S. Worldwide oil and gas platform decommissioning: A review of practices and reefing options. Ocean Coast. Manag. 2019, 168, 274-306. [CrossRef]

292. Macreadie, P.I.; Fowler, A.; Booth, D. Rigs-to-reefs: Will the deep sea benefit from artificial habitat? Front. Ecol. Environ. 2011, 9 , 455-461. [CrossRef]

293. Smyth, K.; Christie, N.; Burdon, D.; Atkins, J.P.; Barnes, R.; Elliott, M. Renewables-to-reefs?-Decommissioning options for the offshore wind power industry. Mar. Pollut. Bull. 2015, 90, 247-258. [CrossRef]

294. Fowler, A.M.; Jørgensen, A.-M.; Coolen, J.W.P.; Jones, D.O.B.; Svendsen, J.C.; Brabant, R.; Rumes, B.; Degraer, S. The ecology of infrastructure decommissioning in the North Sea: What we need to know and how to achieve it. ICES J. Mar. Sci. 2020, 77, 1109-1126. [CrossRef]

295. Kamermans, P.; Walles, B.; Kraan, M.; Van Duren, L.A.; Kleissen, F.; Van Der Have, T.M.; Smaal, A.C.; Poelman, M. Offshore Wind Farms as Potential Locations for Flat Oyster (Ostrea edulis) Restoration in the Dutch North Sea. Sustainability 2018, 10, 3942. [CrossRef]

296. Dundas, S.J.; Levine, A.S.; Lewison, R.L.; Doerr, A.N.; White, C.; Galloway, A.W.E.; Garza, C.; Hazen, E.L.; Padilla-Gamiño, J.; Samhouri, J.F.; et al. Integrating oceans into climate policy: Any green new deal needs a splash of blue. Conserv. Lett. 2020, 13. [CrossRef]

297. EU. Waste Framework Directive; EU: Brussels, Belgium, 2008.

298. Schleisner, L. Life cycle assessment of a wind farm and related externalities. Renew. Energy 2000, 20, 279-288. [CrossRef]

299. Weinzettel, J.; Reenaas, M.; Solli, C.; Hertwich, E.G. Life cycle assessment of a floating offshore wind turbine. Renew. Energy 2009, 34, 742-747. [CrossRef]

300. Arvesen, A.; Hertwich, E.G. Assessing the life cycle environmental impacts of wind power: A review of present knowledge and research needs. Renew. Sustain. Energy Rev. 2012, 16, 5994-6006. [CrossRef]

301. Wang, Y.; Sun, T. Life cycle assessment of CO2 emissions from wind power plants: Methodology and case studies. Renew. Energy 2012, 43, 30-36. [CrossRef]

302. Huang, Y.-F.; Gan, X.-J.; Chiueh, P.-T. Life cycle assessment and net energy analysis of offshore wind power systems. Renew. Energy 2017, 102, 98-106. [CrossRef]

303. Properzi, S.; Herk-Hansen, H. Life cycle assessment of a $150 \mathrm{MW}$ offshore wind turbine farm at Nysted/Roedsand, Denmark. Int. J. Environ. Sustain. Dev. 2002, 1, 113-121. [CrossRef]

304. Tsai, L.; Kelly, J.C.; Simon, B.S.; Chalat, R.M.; Keoleian, G.A. Life Cycle Assessment of Offshore Wind Farm Siting: Effects of Locational Factors, Lake Depth, and Distance from Shore. J. Ind. Ecol. 2016, 20, 1370-1383. [CrossRef]

305. Berndt, M.L. Influence of concrete mix design on $\mathrm{CO}_{2}$ emissions for large wind turbine foundations. Renew. Energy 2015, 83, 608-614. [CrossRef]

306. Deng, X.; Ge, J. Global wind power development leads to high demand for neodymium praseodymium (NdPr): A scenario analysis based on market and technology development from 2019 to 2040. J. Clean. Prod. 2020, 277, 123299. [CrossRef]

307. Andersen, P.D.; Borup, M.; Krogh, T. Managing long-term environmental aspects of wind turbines: A prospective case study. Int. J. Technol. Policy Manag. 2007, 7, 339-354. [CrossRef]

308. Cousins, D.S.; Suzuki, Y.; Murray, R.; Samaniuk, J.R.; Stebner, A.P. Recycling glass fiber thermoplastic composites from wind turbine blades. J. Clean. Prod. 2019, 209, 1252-1263. [CrossRef]

309. Mamanpush, S.H.; Li, H.; Englund, K.; Tabatabae, A.T. Recycled wind turbine blades as a feedstock for second generation composites. Waste Manag. 2018, 76, 708-714. [CrossRef]

310. Leahy, P. End-of-life Options for Composite Material Wind Turbine Blades: Recover, Repurpose or Reuse? In Proceedings of the 14th SWEDES Conference, Dubrovnik, Croatia, 1-6 October 2019.

311. Worrell, E.; Reuter, M.A. Handbook of Recycling: State-Of-The-Art for Practitioners, Analysts, and Scientists; Elsevier: Oxford, UK, 2014.

312. Lombardi, L.; Carnevale, E.; Corti, A. A review of technologies and performances of thermal treatment systems for energy recovery from waste. Waste Manag. 2015, 37, 26-44. [CrossRef]

313. Nagle, A.J.; Delaney, E.L.; Bank, L.C.; Leahy, P.G. A Comparative Life Cycle Assessment between landfilling and Co-Processing of waste from decommissioned Irish wind turbine blades. J. Clean. Prod. 2020, 277, 277. [CrossRef] 
314. Fonte, R.; Xydis, G. Wind turbine blade recycling: An evaluation of the European market potential for recycled composite materials. J. Environ. Manag. 2021, 287, 112269. [CrossRef] [PubMed]

315. Townsend, T.G.; Powell, J.; Jain, P.; Xu, Q.; Tolaymat, T.; Reinhart, D. Sustainable Practices for Landfill Design and Operation; Springer: New York, NY, USA, 2015.

316. Macaskie, L.E.; Sapsford, D.J.; Mayes, W.M. Resource Recovery from Wastes: Towards a Circular Economy; The Royal Society of Chemistry: London, UK, 2020.

317. Sapsford, D.; Cleall, P.; Harbottle, M. In Situ Resource Recovery from Waste Repositories: Exploring the Potential for Mobilization and Capture of Metals from Anthropogenic Ores. J. Sustain. Met. 2017, 3, 375-392. [CrossRef]

318. Wang, S.; Wang, S.; Liu, J. Life-cycle green-house gas emissions of onshore and offshore wind turbines. J. Clean. Prod. 2019, 210, 804-810. [CrossRef]

319. Deeney, P.; Nagle, A.J.; Gough, F.; Lemmertz, H.; Delaney, E.L.; McKinley, J.M.; Graham, C.; Leahy, P.G.; Dunphy, N.P.; Mullally, G. End-of-Life alternatives for wind turbine blades: Sustainability Indices based on the UN sustainable development goals. Resour. Conserv. Recycl. 2021, 171, 105642. [CrossRef]

320. Morini, A.A.; Ribeiro, M.J.; Hotza, D. Carbon footprint and embodied energy of a wind turbine blade-A case study. Int. J. Life Cycle Assess. 2021, 26, 1177-1187. [CrossRef]

321. Marshall., R.; Velenturf, A.; Jopson, J. Making the Most of Industrial Wastes: Strengthening Resource Security of Valuable Metals for Clean Growth in the UK; Policy and Practice Note; Resource Recovery from Waste: Leeds, UK, 2018.

322. Gomes, H.I.; Mayes, W.; Whitby, P.; Rogerson, M. Constructed wetlands for steel slag leachate management: Partitioning of arsenic, chromium, and vanadium in waters, sediments, and plants. J. Environ. Manag. 2019, 243, 30-38. [CrossRef]

323. Fromer, N.A.; Diallo, M.S. Nanotechnology and clean energy: Sustainable utilization and supply of critical materials. J. Nanoparticle Res. 2013, 15, 2011. [CrossRef]

324. Yang, Y.; Walton, A.; Sheridan, R.; Güth, K.; Gauß, R.; Gutfleisch, O.; Buchert, M.; Steenari, B.-M.; Van Gerven, T.; Jones, P.T.; et al. REE Recovery from End-of-Life NdFeB Permanent Magnet Scrap: A Critical Review. J. Sustain. Met. 2017, 3, 122-149. [CrossRef]

325. Tunsu, C. Hydrometallurgy in the recycling of spent NdFeB permanent magnets. In Waste Electrical and Electronic Equipment Recycling; Woodhead Publishing: Sawston, UK, 2018; pp. 175-211.

326. Chen, P.-C.; Liu, K.-H.; Ma, H.-W. Resource and waste-stream modeling and visualization as decision support tools for sustainable materials management. J. Clean. Prod. 2017, 150, 16-25. [CrossRef]

327. Dawson, D.A.; Purnell, P.; Roelich, K.; Busch, J.; Steinberger, J.K. Low Carbon Technology Performance vs Infrastructure Vulnerability: Analysis through the Local and Global Properties Space. Environ. Sci. Technol. 2014, 48, 12970-12977. [CrossRef]

328. Zhao, W.; Siegel, D.; Lee, J.; Su, L. An Integrated Framework of Drivetrain Degradation Assessment and Fault Localization for Offshore Wind Turbines. Int. J. Progn. Health Manag. 2013, 4, 4. [CrossRef]

329. Cheng, Y.; Cheng, M.; Ge, H.; Guo, Y.; Hao, Y.; Sun, X.; Qin, X.; Lu, W.; Chen, Y.; Du, X. MiDBench: Multimodel Industrial Big Data Benchmark. In Lecture Notes in Computer Science (Including Subseries Lecture Notes in Artificial Intelligence and Lecture Notes in Bioinformatics); Springer: Berlin/Heidelberg, Germany, 2019; Volume 11459 LNCS, pp. 172-185.

330. Burdon, D.; Boyes, S.J.; Elliott, M.; Smyth, K.; Atkins, J.P.; Barnes, R.A.; Wurzel, R.K. Integrating natural and social sciences to manage sustainably vectors of change in the marine environment: Dogger Bank transnational case study. Estuar. Coast. Shelf Sci. 2018, 201, 234-247. [CrossRef]

331. Gumus, S.; Kucukvar, M.; Tatari, O. Intuitionistic fuzzy multi-criteria decision making framework based on life cycle environmental, economic and social impacts: The case of U.S. wind energy. Sustain. Prod. Consum. 2016, 8, 78-92. [CrossRef]

332. Taylor, C.M.; Smith, B.; Stein, D. The role of MarineCadastre. In gov in offshore energy planning. In Proceedings of the OCEANS 2012 MTS/IEEE: Harnessing the Power of the Ocean, Hampton Roads, VA, USA, 14-19 October 2012.

333. Copping, A.; Smith, C.; Hanna, L.; Battey, H.; Whiting, J.; Reed, M.; Brown-Saracino, J.; Gilman, P.; Massaua, M. Tethys: Developing a commons for understanding environmental effects of ocean renewable energy. Int. J. Mar. Energy 2013, 3-4, 41-51. [CrossRef]

334. Mont, O. Innovative approaches to optimising design and use of durable consumer goods. Int. J. Prod. Dev. 2008, 6, 227-250. [CrossRef]

335. Stahel, W.R. The Performance Economy; Palgrave Macmillan: Hampshire, UK, 2010.

336. EC. Directive 2009/125/EC Establishing a Framework for the Setting of Ecodesign Requirements for Energy-Related Products (Recast); EC: Brussels, Belgium, 2009; Volume 2011.

337. Faber, N.; Jorna, R.; van Engelen, J.O. The sustainability of "sustainability" - A study into the conceptual foundations of the notion of "sustainability". J. Environ. Assess. Policy Manag. 2005, 7, 1-33. [CrossRef]

338. Schaumann, P.; Gottschalk, M.; Mickley, M.; Kutterer, H.J.; Neuner, H. Influence of manufacturing aspects on fatigue assessment. In Proceedings of the European Wind Energy Conference and Exhibition 2010, EWEC 2010, Warsaw, Poland, 20-23 April 2010; pp. 3666-3671.

339. Häfele, J.; Rolfes, R. Approaching the ideal design of jacket substructures for offshore wind turbines with a Particle Swarm Optimization algorithm. In Proceedings of the International Offshore and Polar Engineering Conference, Rhodes, Greece, 26 June-2 July 2016; pp. 156-163.

340. Wang, S.; Nejad, A.R.; Moan, T. On design, modelling, and analysis of a 10-MW medium-speed drivetrain for offshore wind turbines. Wind. Energy 2020, 23, 1099-1117. [CrossRef] 
341. Schaumann, P.; Bechtel, A.; Eichstädt, R.; Stranghöner, N.; Berg, J.; Gorbachov, A.; Wagner, H.-J.; Röder, J. Sustainability of steel constructions of renewables. Stahlbau 2014, 83, 487-494. [CrossRef]

342. Schaumann, P.; Bechtel, A. Sustainability assessment of steel constructions of offshore wind energy turbines. Stahlbau 2013, 82 , 665-670. [CrossRef]

343. Schaumann, P.; Bechtel, A.; Wagner, H.J.; Stranghöner, N. Indicators for sustainability assessment of renewables. In Life-Cycle and Sustainability of Civil Infrastructure Systems, Proceedings of the 3rd International Symposium on Life-Cycle Civil Engineering, IALCCE 2012, Vienna, Austria, 3-6 October 2012; Taylor \& Francis Group: London, UK, 2012; pp. 1745-1752.

344. Boero, F.; Foglini, F.; Fraschetti, S.; Goriup, P.; Macpherson, E.; Planes, S.; Soukissian, T.; Adiloglu, B.; Cristens, G.; Delahaye, C.; et al. CoCoNet: Towards coast to coast networks of marine protected areas (From the shore to the high and deep sea), coupled with sea-based wind energy potential. SCIRES-IT 2016, 6, 1-95. [CrossRef]

345. Glisic, A.; Nguyen, N.D.; Schaumann, P. Comparison of integrated and sequential design approaches for fatigue analysis of a jacket offshore wind turbine structure. In Proceedings of the International Offshore and Polar Engineering Conference, Sapporo, Japan, 10-15 June 2018; pp. 440-447.

346. Kennedy, C.; Zhong, M.; Corfee-Morlot, J. Infrastructure for China's Ecologically Balanced Civilization. Engineering 2016, 2, 414-425. [CrossRef]

347. Fogarassy, C.; Horvath, B.; Kovacs, A.; Szoke, L.; Takacs-Gyorgy, K. A Circular Evaluation Tool for Sustainable Event Management-An Olympic Case Study. Acta Polytech. Hung. 2018, 14, 161-177. [CrossRef]

348. Moore, E.A.; Russell, J.D.; Babbitt, C.W.; Tomaszewski, B.; Clark, S.S. Spatial modeling of a second-use strategy for electric vehicle batteries to improve disaster resilience and circular economy. Resour. Conserv. Recycl. 2020, 160, 104889. [CrossRef]

349. Kouloumpis, V.; Yan, X. Sustainable energy planning for remote islands and the waste legacy from renewable energy infrastructure deployment. J. Clean. Prod. 2021, 307, 127198. [CrossRef]

350. Niccolini, F.; Chisari, L.A.; Maggioni, B. Lean Logistics for Green Field Exploration Activities. In Proceedings of the Society of Petroleum Engineers-Abu Dhabi International Petroleum Exhibition and Conference 2019, ADIP 2019, Abu Dhabi, United Arab Emirates, 11-14 November 2019.

351. Busch, J.; Dawson, D.; Roelich, K. Closing the low-carbon material loop using a dynamic whole system approach. J. Clean. Prod. 2017, 149, 751-761. [CrossRef]

352. Busch, J.; Steinberger, J.; Dawson, D.; Purnell, P.; Roelich, K. Managing Critical Materials with a Technology-Specific Stocks and Flows Model. Environ. Sci. Technol. 2014, 48, 1298-1305. [CrossRef]

353. Salim, H.K.; Stewart, R.A.; Sahin, O.; Dudley, M. Drivers, barriers and enablers to end-of-life management of solar photovoltaic and battery energy storage systems: A systematic literature review. J. Clean. Prod. 2019, 211, 537-554. [CrossRef]

354. Chen, W.-M.; Kim, H. Circular economy and energy transition: A nexus focusing on the non-energy use of fuels. Energy Environ. 2019, 30, 586-600. [CrossRef]

355. Klemeš, J.J.; Varbanov, P.; Walmsley, T.G.; Foley, A. Process Integration and Circular Economy for Renewable and Sustainable Energy Systems. Renew. Sustain. Energy Rev. 2019, 116, 109435. [CrossRef]

356. Esteva, L.C.A.; Kasliwal, A.; Kinzler, M.S.; Kim, H.C.; Keoleian, G.A. Circular economy framework for automobiles: Closing energy and material loops. J. Ind. Ecol. 2021, 25, 877-889. [CrossRef]

357. Kylili, A.; Thabit, Q.; Nassour, A.; Fokaides, P.A. Adoption of a holistic framework for innovative sustainable renewable energy development: A case study. Energy Sources Part A Recover. Util. Environ. Eff. 2021. [CrossRef]

358. Abokersh, M.H.; Norouzi, M.; Boer, D.; Cabeza, L.F.; Casa, G.; Prieto, C.; Jiménez, L.; Vallès, M. A framework for sustainable evaluation of thermal energy storage in circular economy. Renew. Energy 2021, 175, 686-701. [CrossRef]

359. Contreras-Lisperguer, R.; Muñoz-Cerón, E.; Aguilera, J.; de la Casa, J. A set of principles for applying Circular Economy to the PV industry: Modeling a closed-loop material cycle system for crystalline photovoltaic panels. Sustain. Prod. Consum. 2021, 28, 164-179. [CrossRef]

360. Levinthal, D.; March, J.G. A model of adaptive organizational search. J. Econ. Behav. Organ. 1981, 2, 307-333. [CrossRef]

361. March, J.G. Exploration and Exploitation in Organizational Learning. Organ. Sci. 1991, 2, 71-87. [CrossRef]

362. Gunderson, L.H.; Holling, C.S. Resilience and Adaptive Cycles. In Panarchy: Understanding Transformations in Human and Natural Systems; Gunderson, L.H., Holling, C.S., Eds.; Island Press: Washington, DC, USA, 2002.

363. Velenturf, A.P.M. Promoting industrial symbiosis: Empirical observations of low-carbon innovations in the Humber region, UK. J. Clean. Prod. 2016, 128, 116-130. [CrossRef]

364. IPCC. AR6 Climate Change 2021: The Physical Science Basis; IPCC: Geneva, Switzerland, 2021.

365. Stamper, C.; Velenturf, A. Creating Value with Sustainable Decommissioning: Learning from Best Practice in North Sea Oil and Gas, and Offshore Wind; Leeds University: Leeds, UK, 2020.

366. Pearce, F. 101 things to do with an old oil rig. New Sci. 1996, 152, $26-29$.

367. Papathanasopoulou, E.; Beaumont, N.; Hooper, T.; Nunes, J.; Queirós, A.M. Energy systems and their impacts on marine ecosystem services. Renew. Sustain. Energy Rev. 2015, 52, 917-926. [CrossRef]

368. Millward-Hopkins, J.; Busch, J.; Purnell, P.; Zwirner, O.; Velis, C.A.; Brown, A.; Hahladakis, J.; Iacovidou, E. Fully integrated modelling for sustainability assessment of resource recovery from waste. Sci. Total Environ. 2018, 612, 613-624. [CrossRef] [PubMed] 